\title{
Milk Proteins, Peptides, and Oligosaccharides: Effects against the 21st Century Disorders
}

\author{
Chia-Chien Hsieh, ${ }^{1}$ Blanca Hernández-Ledesma, ${ }^{2}$ Samuel Fernández-Tomé, ${ }^{2}$ \\ Valerie Weinborn, ${ }^{3,4}$ Daniela Barile, ${ }^{3,4}$ and Juliana María Leite Nobrega de Moura Bell ${ }^{3,4}$ \\ ${ }^{1}$ Department of Human Development and Family Studies (Nutritional Science \& Education), National Taiwan Normal University, \\ No.162, Section 1, Heping East Road, Taipei 106, Taiwan \\ ${ }_{2}^{2}$ Instituto de Investigación en Ciencias de la Alimentación (CIAL, CSIC-UAM, CEI UAM+CSIC), Nicolás Cabrera 9, \\ 28049 Madrid, Spain \\ ${ }^{3}$ Food Science Department, University of California, Davis, One Shields Avenue, Davis, CA 95616, USA \\ ${ }^{4}$ Foods for Health Institute, University of California, Davis, One Shields Avenue, Davis, CA 95616, USA
}

Correspondence should be addressed to Blanca Hernández-Ledesma; b.hernandez@csic.es

Received 21 October 2014; Accepted 21 December 2014

Academic Editor: Jinsong Ren

Copyright (C) 2015 Chia-Chien Hsieh et al. This is an open access article distributed under the Creative Commons Attribution License, which permits unrestricted use, distribution, and reproduction in any medium, provided the original work is properly cited.

\begin{abstract}
Milk is the most complete food for mammals, as it supplies all the energy and nutrients needed for the proper growth and development of the neonate. Milk is a source of many bioactive components, which not only help meeting the nutritional requirements of the consumers, but also play a relevant role in preventing various disorders. Milk-derived proteins and peptides have the potential to act as coadjuvants in conventional therapies, addressing cardiovascular diseases, metabolic disorders, intestinal health, and chemopreventive properties. In addition to being a source of proteins and peptides, milk contains complex oligosaccharides that possess important functions related to the newborn's development and health. Some of the health benefits attributed to milk oligosaccharides include prebiotic probifidogenic effects, antiadherence of pathogenic bacteria, and immunomodulation. This review focuses on recent findings demonstrating the biological activities of milk peptides, proteins, and oligosaccharides towards the prevention of diseases of the 21st century. Processing challenges hindering large-scale production and commercialization of those bioactive compounds have been also addressed.
\end{abstract}

\section{Introduction: Role of Milk in Human Health}

Milk, as the first food for mammals, supplies all the energy and nutrients needed for the proper growth and development of the neonate. For all mammalians, the consumption of milk ends at the weaning period with the exception of humans that continue consuming milk throughout their life. Milk and derived dairy products are considered an important constituent of a balanced diet. Moreover, it is a source of many bioactive components, such as high-quality proteins, lipids, carbohydrates, lactose, vitamins, minerals, enzymes, hormones, immunoglobulins, and growth factors, among others. These components not only help meeting human nutritional requirements, but also play a relevant role in preventing various disorders such as hypertension and cardiovascular diseases [1], obesity [2], osteoporosis [3], dental caries [4], poor gastrointestinal health [5], colorectal cancer [6], ageing [7], and others [8].

Milk proteins supply nitrogen and amino acids to young mammals and possess multiple physiological properties in the intact form. Moreover, studies carried out in the past decades have demonstrated the role of these proteins as a source of biologically active peptides. Bioactive peptides are inactive within the sequence of the parent protein but, once released by in vitro processing conditions or by in vivo gastrointestinal digestion, are capable of acting as regulatory compounds exerting a positive impact on body functions and ultimately promoting health benefits to the consumer [9] .

Human milk is undoubtedly the most complete source of nourishment for the newborn. Breastfed infants have been 
TABLE 1: Commercial milk products containing peptides with proven antihypertensive activity.

\begin{tabular}{lcccc}
\hline Commercial name & Obtention process & Protein source & Active sequence(s) & $\begin{array}{c}\text { Publication } \\
\text { number [reference] }\end{array}$ \\
\hline $\begin{array}{lccc}\text { Peptide C12 } \\
\text { Biozate }\end{array}$ & Hydrolysis with trypsin & $\alpha_{\text {s1 }}$-Casein & FFVAPFPEVFGK & JP62270533 [31] \\
Lowpept & Hydrolysis with trypsin & Whey proteins & Whey peptides & US6998259 [157] \\
Calpis & Hydrolysis with pepsin & $\alpha_{\text {s1 }}$-Casein & RYLGY, AYFYPEL & WO2005012355 \\
Evolus & Fermentation & $\beta$-Casein & VPP, IPP & US5449661A \\
\hline
\end{tabular}

shown to be less susceptible to diseases (i.e., diarrhea and respiratory diseases) than those that were not breastfed. This protective effect, which was previously attributed to human milk antibodies, is today strongly correlated with the presence of complex oligosaccharides (OS), the third most abundant component of human milk [10]. Human milk is composed of OS in concentrations varying according to different stages of lactation: $20-23 \mathrm{~g} / \mathrm{L}$ in colostrum and $12-14 \mathrm{~g} / \mathrm{L}$ in mature milk [11], being even more abundant than proteins $(12 \mathrm{~g} / \mathrm{L})$ [12]. Human milk oligosaccharides (HMO) are complex sugars having 3 to 20 monosaccharide units [13] that are not digestible by human enzymes [14]. These compounds have important functions related to the newborn's development and health at local and systemic levels, including prebiotic probifidogenic effects and antiadherence of pathogenic bacteria [15], brain development [16], and immunomodulatory properties [17], among others.

In the last fifty years, chronic disorders have become the leading cause of morbidity and mortality in industrialized countries, with increasing incidence also observed in developing countries. Chronic disorders include cardiovascular and neurological diseases, stroke, cancers, immune disorder and chronic respiratory disease, obesity, diabetes, and metabolic syndrome [18]. In Europe, $87 \%$ of all deaths occur due to chronic diseases and the number of people affected is expected to rise considerably over the next few decades. The majority of chronic diseases are caused by risk factors which are mostly preventable. Diet and lifestyle are two environmental factors that strongly affect these diseases; thus modifications of these habits are becoming a new strategy for disease prevention/treatment.

The aim of this paper is to review the recent literature on the physiological effects of proteins, peptides, and oligosaccharides with special emphasis on animal and human trials. Other aspects such as the limited availability of in vivo studies demonstrating the biological activities of OS from bovine and caprine milk and the current challenges associated with the recovery and commercial production of these compounds have also been addressed.

\section{Impact of Milk Proteins and Peptides on the 21st Century Diseases}

2.1. Milk-Derived Peptides against Cardiovascular Diseases. Cardiovascular diseases (CVD) have become the leading cause of morbidity and mortality worldwide, representing an important medical and public health issue [19]. Although earlier studies associated the consumption of whole milk with higher incidence of CVD, it has been demonstrated that milk contains a plethora of bioactive substances which may contribute to the prevention of most of the risk factors of CVD [20]. Recently, bioactive milk peptides have gained interest because of their notable antihypertensive, antioxidant, antiinflammatory, and hypocholesterolaemic effects. In this section, the most current scientific information regarding in vitro and in vivo studies on the role of milk proteins-derived peptides on CVD is summarized and discussed.

2.1.1. Milk Peptides with Antihypertensive Activity. Epidemiological studies suggest that the dietary intake of milk and dairy foods is related to decreased risk of hypertension [21]. In addition to their high mineral content (e.g., calcium, potassium, and magnesium) that can lower blood pressure [22], other milk components, such as proteins and their hydrolyzed products, have been also linked to the antihypertensive effect of milk and dairy products. Angiotensinconverting enzyme (ACE) is a multifunctional enzyme that acts as one of the main regulators of blood pressure. Thus, ACE inhibition is currently considered as one of the best strategies for hypertension treatment. Most biologically active peptides generated from milk proteins have demonstrated ACE inhibitory activity. In the last two decades, antihypertensive effects of some of these peptides have been evaluated in spontaneously hypertensive rats (SHR) and hypertensive humans, and the peptide sequences, doses, and maximum decreases of systolic blood pressure (SBP) have been summarized in several reviews [23-25]. The hydrolyzate obtained by the action of pepsin on casein, containing the $\alpha_{\text {s1 }}$-casein-derived peptides RYLGY and AYFYPEL, has been patented and commercialized under the name of Lowpept by its antihypertensive properties demonstrated in both SHR [26] and hypertensive humans [27] (Table 1). Pepsin has been also used to hydrolyze whey protein lactoferrin, with the release of peptides containing ACE activity and ACE-dependent vasoconstriction inhibitory properties [28]. Antihypertensive effects in SHR after short-term and longterm treatments have been also observed for those peptides $[29,30]$. Trypsin is another gastrointestinal enzyme used to release the antihypertensive peptide $\alpha_{\mathrm{s} 1}$-casein peptide f(2334) from casein during the manufacture of the commercial 
ingredient peptide $\mathrm{C} 12[31,32]$ (Table 1). In addition to the use of gastric and pancreatic enzymes, alone or in combination, to produce antihypertensive peptides, the use of food-grade enzymes derived from microorganisms has become common for the release of peptides with demonstrated SBP lowering effects in SHR [33-36].

Milk fermentation is another strategy to produce antihypertensive peptides by the proteolytic action of lactic acid bacteria on milk proteins. The most representative peptides are those derived from $\beta$-casein and identified in sour milk fermented by Lactobacillus helveticus and Saccharomyces cerevisiae (Calpis, Table 1). These tripeptides, with sequences VPP and IPP, have demonstrated an ability to exert potent decreasing effects on the SBP of SHR [37, 38]. A number of clinical trials have been conducted to confirm their antihypertensive properties in humans although controversial results have been found. Three meta-analyses performed with the published data of 17 [39], 12 [40], and 28 [41] clinical trials have reported an average decrease in SBP of $5.1,4.8 \mathrm{~mm}$, and $1.7 \mathrm{~mm}$ of $\mathrm{Hg}$, respectively. However, no effects were found in Dutch and Danish subjects consuming fermented milk containing peptides VPP and IPP [42, 43]. A recent meta-analysis including 18 trials has reported higher antihypertensive effects for these two tripeptides in Asian than in Caucasian people [44]. Those findings suggest that genetics and/or dietary patterns might exert an important influence on the antihypertensive effects of peptides IPP and VPP. Similarly, the age has been described as another major influencing factor [45]. With the evidence presented to date, the European Food Safety Authority (EFSA) Panel on Dietetic Products, Nutrition and Allergies (NDA) [46] concluded that there are no sufficient data to establish a cause/effect relationship between the consumption of peptides VPP and IPP and the control of hypertension, and further studies are thus required. Other peptides derived from $\beta$-casein during milk fermentation with Enterococcus faecalis, in which sequences are LHLPLP and HLPLP, have also shown antihypertensive effects in SHR [47]. In recent studies, fermented milk with Lactococcus lactis NRRLB-50571 and NRRLB-50572 has presented important SBP, diastolic blood pressure (DBP), and heart rate-lowering effects in SHR $[48,49]$ although the peptides responsible for the activity have not been identified.

Accumulating evidence built in animal and clinical studies is currently available on the antihypertensive activity of milk-derived peptides. However, much work is still needed. Identification of the active form reaching the target organs and elucidation of its bioavailability after oral ingestion and its complete mechanism of action are two of the main aspects required to be deeply investigated in the future to support health claims.

2.1.2. Antioxidant and Anti-Inflammatory Milk-Derived Peptides. Oxidative stress is one of the main responsible factors for the initiation or evolution of CVD. The search of natural antioxidants providing additional benefits to the endogenous antioxidant defense system is gaining interest [50]. Among food-derived peptides with antioxidant properties without harm side effects, those derived from milk proteins are most frequently studied. The majority of the studies carried out to characterize antioxidant peptides derived from casein and whey proteins have only used in vitro chemical assays $[51,52]$. However, their limited similarity to physiological conditions makes the in vitro assays very restrictive, and reported effects need to be confirmed by animal models and/or human trials. Nevertheless, to date, just few in vivo trials have been carried out to demonstrate the antioxidant effects of milkderived peptides related to benefits on cardiovascular health. Zommara et al. [53] reported the antiperoxidative action of fermented milk on rats fed a vitamin-E deficient diet. The consumption of fermented milk by healthy subjects has been also demonstrated to lower the levels of oxidized low-density lipoprotein, isoprostanes, and the glutathione redox ratio. Improvements of total plasma antioxidant activity and of the resistance of the lipoprotein fraction to oxidation have resulted in enhanced antiatherogenicity [54]. The compounds responsible for the observed effects have not been identified yet, although milk peptides liberated during fermentation process might have a crucial role. Thus, further studies focused on evaluating the potential of milk-derived peptides as antioxidant at cardiovascular level should be of great relevance.

Chronic inflammation is another responsible factor for the development of CVD. The downregulation of cytokines involved in the inflammation-associated endothelial dysfunction by food components, including peptides, may delay or alleviate inflammation, thus exerting favorable effects against CVD [55]. A recent study using lipopolysaccharide(LPS-) stimulated mouse macrophages has reported the ability of a yak casein hydrolyzate to reduce the secretion of proinflammatory cytokines and the production of nitric oxide and to scavenge free radicals, suggesting a potential role as preventive agent against inflammation related disorders [56]. To date, only one human trial has been conducted to demonstrate the anti-inflammatory properties of milk peptides. This study reported an improvement in the vascular function through modulation of the glucose levels and inflammation and oxidative stress biomarkers after the consumption of the commercial whey derived peptide NOP47 by healthy individuals [57]. This finding opens a new door towards searching of new milk-derived peptides with antioxidant and anti-inflammatory activity.

2.1.3. Hypocholesterolaemic Milk Peptides. Blood lipids are represented in various forms including total cholesterol, triglycerides, lipoproteins (high-density lipoproteins or HDL, low-density lipoproteins or LDL, and very-low-density lipoproteins or VLDL), and free fatty acids. An inappropriate ratio of these lipids is one of the most important risk factors for developing CVD. Therefore, CVD therapy/prevention strategies focus on reaching an optimal lipid balance in order to achieve a positive cardiovascular health. Those therapies aim at increasing the physiological levels of desirable lipids (e.g., HDL cholesterol) while reducing the others associated with atherogenic functions (e.g., LDL cholesterol, triglycerides). Milk proteins, mainly whey proteins 
and derived hydrolyzates or peptides, have been reported to exert hypocholesterolaemic effects in different animal models. The ingestion of whey protein was correlated with a significant reduction of total cholesterol levels in rats fed with cholesterol-free and cholesterol-enriched diets $[58,59]$. Nagaoka et al. [60] have reported similar effects for a $\beta$ lactoglobulin tryptic hydrolyzate administered to rats fed with a diet rich in cholesterol. The hydrolyzate reduced total cholesterol and increased HDL cholesterol and fecal steroid excretion. The fragment $\mathrm{f}(71-75)$ of this whey protein, known as lactostatin, with sequence IIAEK, has been reported as the main factor responsible for the observed effects [60]. $\beta$-Lactotensin, another $\beta$-lactoglobulin peptide, released by chymotrypsin hydrolysis, decreased total cholesterol, LDL, and VLDL cholesterol content in mice fed with a cholesterolenriched diet [61]. Although the mechanism of action of those peptides has not been completely elucidated, preliminary results suggest a key role played by the amino acid composition [50]. Further studies are clearly needed to corroborate those results. The exact mode of this hypocholesterolaemic action needs to be determined in clinical trials.

\subsection{Milk-Derived Hydrolyzates and Peptides on Intestinal} Health. The gastrointestinal tract (GIT) serves as a specialized interface between the body and the external environment. The GIT is strategically covered by a monolayer of specially designed epithelial cells continually exposed to a high concentration of food components and substances along the gut luminal surface. Hence, the modulator effect of the diet on GIT functions has been accepted as essential for maintaining and improving the general health of the host [62]. Interestingly, more than $70 \%$ of the current "food for specified health uses products" (FOSHU) are related to GIT functions [63].

Dairy proteins, hydrolyzates, and peptides have been demonstrated to transform the dynamics of mucus mainly via influencing the mucin secretion and expression and the number of goblet cells. In ex vivo preparations of rat jejunum, casein hydrolyzates increased mucin secretion $[64,65]$. The $\beta$-casein derived peptide $\beta$-casomorphin 7 produced the same effects which have been suggested to be mediated by interaction with opioid receptors. Also, this peptide has been reported to stimulate the expression of mucin $M u c 2$ and $M u c 3$ genes in rat intestinal DHE cells and MUC5AC gene in human intestinal HT29-MTX cells [66]. Another $\beta$-casein fragment, $\mathrm{f}(94-123)$, identified in commercial yoghurt, also had the ability to increase the mucin output and the mRNA levels of MUC2 and MUC4 genes in HT29-MTX cells [67]. Casein and whey proteins hydrolyzates have been reported to be a source of peptides with capacity to induce mucin secretion and MUC5AC gene expression in HT29-MTX cells [68]. Among these peptides, the $\alpha_{\mathrm{s} 1}$-casein fragments $\mathrm{f}(143-$ $149)$ and $\mathrm{f}(144-149)$ and the $\beta$-lactoglobulin fragment $\mathrm{f}(102-$ 105) known as $\beta$-lactorphin were suggested as the major peptides responsible for the observed effects.

A few in vivo studies have also pointed out the regulation of the protective mucus layer by dairy proteins and products thereof. Rats fed with a diet based on casein hydrolyzates, as the exclusive source of nitrogen, were found to enhance their endogenous nitrogen flow and expression of mucin genes $M u c 3$ and Muc4 in the small intestine and colon, respectively [69]. Plaisancié et al. [67] reported the capacity of the $\beta$ casein fragment $\mathrm{f}(94-123)$, once orally ingested by rats, to upregulate the Muc2, Muc4, rat defensing 5 and lysozyme mRNA transcripts expression, the goblet cells recounts, and the number of crypts containing Paneth cells in the rat small intestine. In the dextran sulphate sodium- (DSS-) induced model of rat colitis, the studies of Sprong et al. [70] and Faure et al. [71] demonstrated the gut-protective effects exerted by a cheese whey protein diet and a diet supplemented with Thr, Ser, Cys, and Pro residues, respectively. Moreover, this protection has been reported for a whey protein isolate and $\alpha$ lactalbumin hydrolyzate against chemical-induced ulcerative gastric lesions [72, 73].

Enhancement of the mucosal immune response is also a dietary modulating strategy of the defense systems protecting the GIT. Animal models have proved the improvement of the mucosal immunity by promotion of gut-related immunoglobulin (Ig) levels after ingestion of lactoferrin or its derived peptides, lactoferricin and lactoferrampin [74, 75]. Likewise, immunomodulatory effects have been reported for a trypsin casein hydrolyzate in newborn calves [76] and casein phosphopeptides (CPPs) and peptides released from Lactobacillus helveticus R389-fermented milk in mice [77, 78]. Furthermore, Kitamura and Otani [79] demonstrated that ingestion by healthy humans of CPPs-enriched cakes induced an increase in the faecal IgA content, suggesting a positive effect on mucosal immunity.

Oxidative and inflammatory imbalances are both involved in the etiology of several human chronic gut-related disorders such as ulcerative colitis and Crohn's disease. The search of natural preventive treatments against these imbalances is being prompted [80, 81]. Whey protein has been suggested to exert beneficial effects through enhancement of antioxidant enzymes and downregulation of both oxidative markers and proinflammatory cytokines [82]. These protective findings were found in animal $[83,84]$ and humans trials $[85,86]$. The whey-derived peptide caseinomacropeptide has been proven to have protective properties in the 2,4,6-trinitrobenzene sulphonic acid (TNBS) and DSSinduced model of rat ileitis and colitis, through immunomodulation of the regulatory $\mathrm{T}$ helper cells activation and interleukin secretions $[87,88]$. Turbay et al. [89] demonstrated, in the TNBS-induced murine colitis model, the anti-inflammatory effects exerted by $\beta$-casein hydrolyzates generated by the cell envelope-associated proteinase of Lactobacillus delbrueckii ssp. lactis CRL 581. However, peptides released and responsible for the observed bioactivity have not been identified yet.

\subsection{Milk Proteins and Peptides against Metabolic Disorders.} Diabetes mellitus is considered one of the most common metabolic disorders and one of the major health problems worldwide. It affects almost $6 \%$ of the world's population, with type 2 diabetes representing approximately $90-95 \%$ of the diagnosed cases [90]. Diet and lifestyle interventions 
are the preferred treatment strategies for this metabolic disorder, with pharmacotherapy being prescribed only if supervised lifestyle intervention fails [91]. Epidemiological evidence supports that consumption of milk and dairy foods is associated with a lower incidence of type 2 diabetes. These beneficial effects on metabolic and inflammation factors linked to diabetes and insulin resistance have been also demonstrated by cell and animal models, being multiple milk components, such as calcium, medium-chain fatty acids, linoleic conjugated acid, lactose, citrate, proteins, and peptides characterized as the main responsible factors for the observed effects acting through different mechanisms of action [92].

During the ingestion of a meal, the presence of nutrients at gastrointestinal level stimulates the secretion of two incretins hormones, the glucagon-like peptide-1 (GLP-1) and the glucose-dependent insulinotropic polypeptide (GIP). Both hormones are implicated in the stimulation of the insulin secretion from the pancreatic $\beta$-cells, secretion of gastric and pancreatic enzymes, and modulation of gut motility and nutrient absorption, allowing the clearance of the absorbed glucose [93]. Type 2 diabetes is characterized by different disorders including progressive dysfunction of pancreatic cells, insulin resistance, and augmented production of hepatic glucose [94]. Continuous intravenous administration of GLP-1 has been demonstrated to normalize blood glucose levels in diabetic subjects [95]. However, the rapid degradation of this hormone by the enzyme dipeptidyl peptidase-IV (DPP-IV) and its consequent inactivation makes this type 2 diabetes treatment strategy impracticable. Currently, specific DPP-IV inhibitors are thus incorporated to GLP-1 analogues in new oral therapies against this metabolic disease [96].

Diet supplementation with whey protein is currently under preclinical and clinical trials as a promising alternative in the prevention and/or treatment of type 2 diabetes and related diseases [97, 98]. Several mechanisms of action have been suggested for whey protein, including the stimulation of insulin release, improvement of glucose tolerance in diabetic patients, reduction of body weight, and modulation of gut hormones such as cholecystokinin, leptin, and GLP-1 [99]. In the last years, the role of peptides released during the transit of whey proteins through the GIT on the observed effects has been hypothesized [100]. Cell culture and animal models have been used to confirm this hypothesis. A dose-dependent insulinotropic activity of whey protein hydrolyzates has been observed in a cell-based coculture using pancreatic BRINBD11 cells and Caco- 2 cells monolayers [101]. These authors also observed that the oral administration of the hydrolyzates to obese mice evoked an improvement of blood glucose clearance, reduction of hyperinsulinemia, and restoration of the pancreatic capacity to secrete insulin in response to glucose. The main mechanism of action suggested for these hydrolyzates is the DPP-IV inhibitory activity exerted by the peptides contained in them [102]. Among the bioactive peptides described to date, sequences derived from $\beta$ lactoglobulin IPA and IPAVF are the most potent as DPPIV inhibitors $[103,104]$. Another $\beta$-lactoglobulin fragment with sequence VAGTWY has been also demonstrated to exert hypoglycemic effects in the oral glucose tolerance test in mice
[105]. Likewise, both in vitro DPP-IV inhibitory and in vivo hypoglycemic effects have been reported for peptides released from caseins [106]. Recent in silico studies have shown that both caseins and whey proteins might serve as precursors of DPP-IV inhibitory peptides because of the high number of fragments contained within them that match DPP-IV inhibitory sequences $[107,108]$. Thus, this research area holds a great potential, and currently a number of investigations are focused on the identification of new milk proteins-derived peptide with capacity to prevent diabetes and associated metabolic syndromes.

2.4. Chemopreventive Role of Milk Proteins and Peptides. Cancer is the second leading cause of mortality worldwide, and its incidence will continue rising in the next few years in spite of the important advances achieved in the development of cancer therapies. It has been estimated that, by 2020, approximately 15 million new cancer cases will be diagnosed, and 12 million cancer patients will die [109]. It is well known that $35 \%$ of cancer deaths are attributed to diet and its food components [110]. However, cell culture and animal and human trials results have shown that an important number of food constituents can lower cancer risk and even sensitize tumor cells against anticancer therapies [111]. In the last few years, food proteins and derived peptides have become one of the food components with the most promising preventive properties against cancer initiation, promotion, and progression stages [112].

Among the milk proteins, lactoferrin and its derived peptide lactoferricin are the most studied. For both compounds, their antioxidant, immunomodulatory, and antiinflammatory activities are closely linked to their protective effects against cancer (Table 2). Lactoferrin acts by inducing apoptosis, inhibiting angiogenesis, and modulating carcinogen metabolizing enzymes, in addition to its antioxidant and immunomodulatory properties [113]. Moreover, lactoferricin has shown potent anticancer properties in different cell lines, including breast, colon, fibrosarcoma, leukemia, and oral and ovarian cancer cells, without harming normal lymphocytes, fibroblasts, or endothelial or epithelial cells [114]. Also, animal models have confirmed the beneficial properties of this milk-derived peptide. The possible mechanism of bovine lactoferricin in anticarcinogenesis has been shown to be related to its ability to induce apoptosis. It is its strongly cationic nature that allows this peptide to target negatively charged cancer cells with the outer membrane [115]. The suppressed ability in angiogenesis of bovine lactoferricin was in vitro and in vivo demonstrated to contribute to its chemopreventive properties [116]. A significant inhibition of tumor growth and of liver and lung metastasis was reported after subcutaneous administration of bovine lactoferricin in both spontaneous and experimental metastasis mice models [117]. Similar results were observed after subcutaneous treatment and repeated injections of this peptide on Meth A fibrosarcoma xenografts mice and established neuroblastoma xenografts, respectively $[118,119]$.

$\alpha$-Lactalbumin is a whey protein with anticancer properties which has been reported when it forms a complex with 


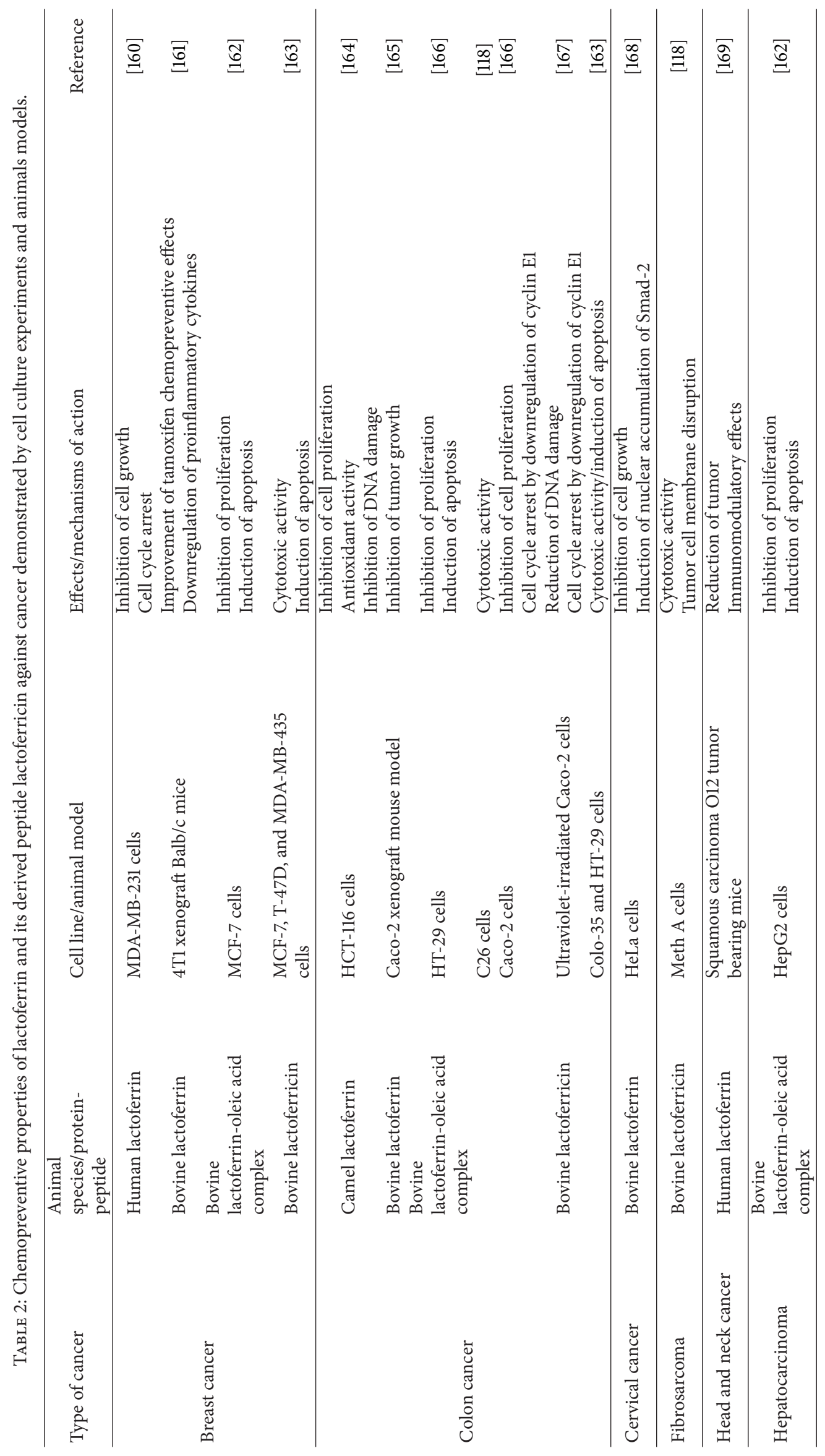




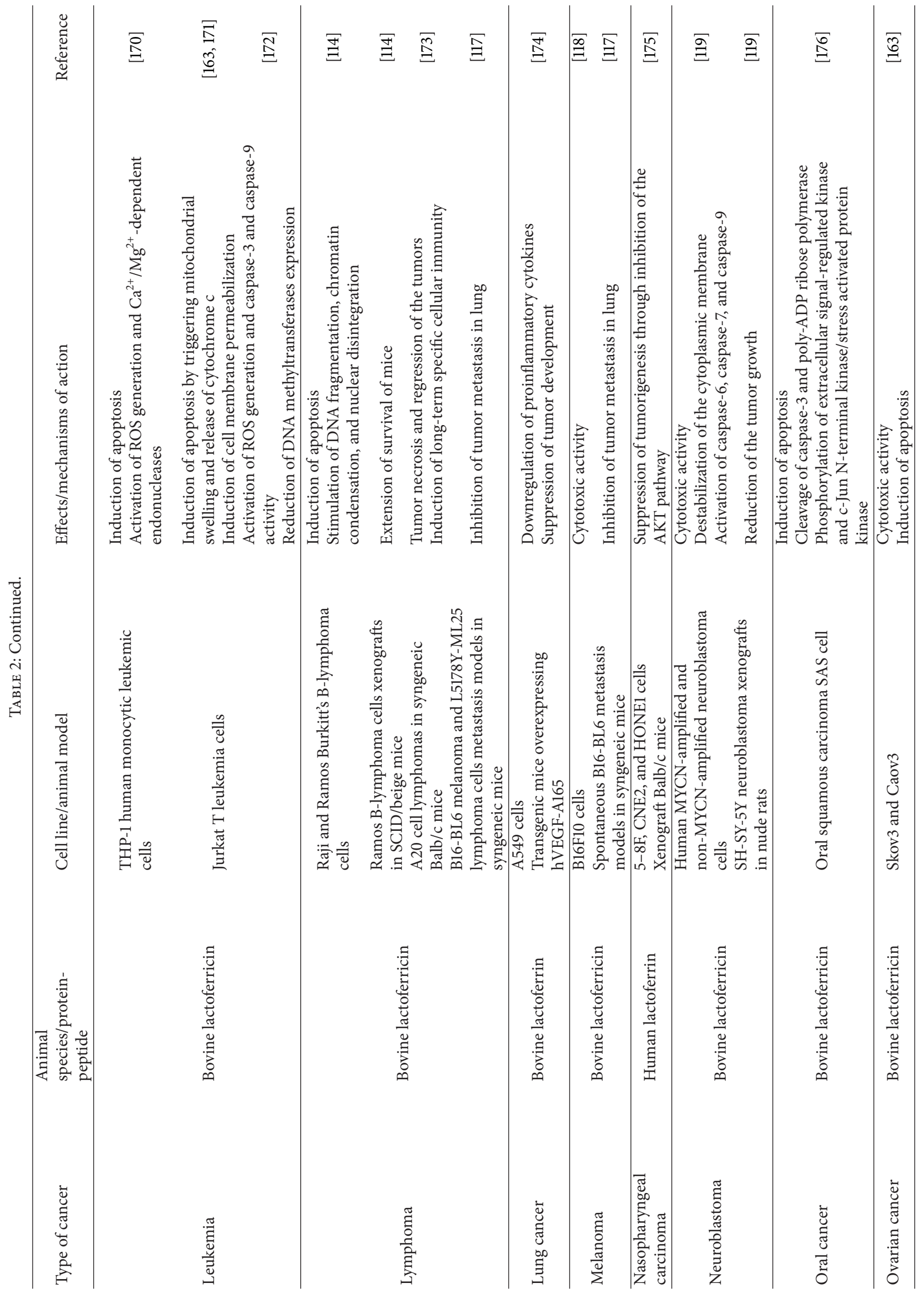


oleic acid known as "human alpha-lactalbumin made lethal to tumor cells, HAMLET" or "bovine alpha-lactalbumin made lethal to tumor cells, BAMLET.” It has been recognized that both protein and fatty acid are required to show cytotoxic activity against cancer cells [115]. Treatment of cancer cells with HAMLET provokes morphological changes typical of apoptotic cells through caspase activation and causes mitochondrial permeability transition resulting in mitochondrial swelling, loss of mitochondrial membrane potential, and cytochrome $\mathrm{c}$ release [120]. These authors also found that this complex induced autophagic cell death and changes in the proteasome structure and function. Similar effects resulting from chromatin condensation and cell shrinkage have been observed after treatment of cancer cells with the complex BAMLET. The efficacy of both complexes has been shown to be influenced by the type of cancer cell line [120]. In the last years, the therapeutic effects against bladder cancer have been studied in animal models as preliminary step for BAMLET use in human trials. It has been demonstrated that intravesical administration of HAMLET delays tumor progression in a murine bladder cancer model although no preventive effects on tumor formation were observed [121].

Intact caseins have not been characterized as chemopreventive proteins but they have been suggested as an important source of peptides with anticancer properties. CPPs are able to bind calcium, to inhibit cell proliferation, and to induce apoptosis of intestinal tumor HT-29 and AZ-97 cells through activation of voltage-activated calcium channels, which mediate the calcium flood according to the depolarization state of the cell [122]. However, in differentiated epithelial intestinal cells, a protective effect from programmed cell death is observed after treatment with these peptides [123]. $\beta$-Casomorphin 7 and $\beta$-casomorphin 5, two casein-derived sequences with opioid properties, have shown antiproliferative and cell cycle arresting activities on breast and colon cancer cells $[115,124,125]$. It has been suggested that these effects are mediated by interaction with specific opioid and somatostatin receptors although further studies confirming this mode of action are needed.

\section{Impact of Milk Oligosaccharides on Human Health}

Despite the important role of HMO in infant health, the limited supply of human milk has hindered its use in commercial infant formula [126] and in large-scale clinical trials. Presumably, the health benefits provided by HMO to infants could be extended to humans of all ages if alternative sources of these complex OS are identified [127]. In that view, the need of finding other sources of human-like OS has prompted the identification, characterization, and quantification of unknown OS present in many other types of milk and their respective industrial streams [128, 129].

3.1. Alternative Sources of Oligosaccharides: Major Sources of Nonhuman Milk Oligosaccharides and Their Industrial Effluents. Increasing interest on plant- and lactose-derived OS has been observed in the past decade as an alternative source for complex HMO. Some of these OS include galactoOS (GOS), fructo-OS (FOS), and lactulose, among others [130]. These indigestible OS are considered prebiotics due to their ability to confer health benefits to the host through the selective growth and activity of commensal bacteria [131]. One such example is inulin, an oligofructan with Dfructofuranosyl $\beta(1-2)$ links that cannot be broken down by human digestive enzymes, thus exerting several intestinal physiological effects that contribute to the host health. GOS, commonly produced by transgalactosylation of lactose by $\beta$-galactosidases, are another example of a current available source of OS for use by the infant formula industry.

Despite the fact that some health promoting effects, such as improved bifidogenic activity, have been attributed to some of those OS [131], little similarity has been observed between commercially available GOS and HMO, except that they are both built on a lactose core [127]. GOS and FOS are composed of a simple linear core, being devoid of structures having high biological activity such as fucose, sialic acid, and $N$ acetyl glucosamine. Because GOS and FOS do not possess the intrinsic structural complexity observed in HMO, it is expected that domestic farm animals and their processing streams, such as whey permeate from cheese manufacturing, can be a source of OS more similar to the ones present in human milk [132].

World milk production is almost entirely derived from cattle $(83 \%)$, buffaloes $(13 \%)$, goats $(2 \%)$, sheep $(1 \%)$, and camels (0.3\%) (http://www.fao.org/agriculture/dairy-gateway/milk-production/dairy-animals/en/\#.VA95gvldXXs). Considering that cow milk accounts for $83 \%$ of the world milk production, the enormous interest of the scientific community to identify, quantify, and characterize the OS present in cattle milk and their industrial byproducts is not surprising. A comprehensive review by Urashima et al. [132] shows that approximately 25 bovine milk OS (BMO) structures had been characterized before 2011. The development of advanced analytic techniques, such as several mass spectrometric methods and hydrophilic interaction liquid chromatography-high performance liquid chromatography, has enabled significant improvement in the identification of new BMO; as many as 40 BMO have been characterized $[133,134]$.

The low concentration of BMO makes it challenging to identify and characterize these compounds when compared with $\mathrm{HMO}$. The OS concentration can reach values as high as $0.7-1.0 \mathrm{~g} / \mathrm{L}$ in bovine colostrum or can be detected as just trace amounts in bovine milk [135], being much lower than the OS concentration in human milk. Caprine milk is another type of milk, which contains complex OS similar to HMO. The discovery of the presence of fucosylated and sialylated OS that are considered as prebiotics and which have the ability to reduce pathogen adherence to the intestine wall has opened up translational opportunities to human health [136]. Approximately 37 caprine milk OS (COS) have been identified, of which nearly half of them have had their structural complexity elucidated. Similar to bovine milk, COS are present in very small concentrations when compared with HMO. However, they have been found in concentrations of 0.25-0.3 g/L, which is 4-5 times higher than BMO [137]. 
From those two alternative sources of HMO-like OS (BMO and COS), industrial streams arising from cheese manufacturing and production of whey protein concentrates (WPC) and isolates (WPI) have been considered as a more realistic source of OS for future commercialization $[129,138]$. Considering the enormous worldwide production of whey (180-190 × $10^{6}$ tonnes/year; http://www.adpi.org/ Portals/0/PDF/09Conference/TAGEAFFERTSHOLT.pdf) and the fact that the major industrial application of whey to produce WPC and WPI generates a new byproduct containing the target OS, the development of economically feasible processes to recover these compounds represents a key step in enabling the large-scale production of OS.

3.2. Biological Activities of Oligosaccharides. While a wide range of biological functions has been attributed to HMO, less information is available regarding the biological activities of BMO and COS. The limited availability of large quantities of OS with high degree of purity can be inferred by the limited number of in vivo studies with those compounds, with the majority of milk OS biological activities being described by in vitro studies. Recent reports of some of the biological activities of HMO, BMO, and COS are reported in Table 3.

3.2.1. Prebiotic Activity. One of the main features of $\mathrm{HMO}$ is that they can only be consumed by very specific bacteria strains that possess the appropriate set of enzymes to cleave their complex structure. This prebiotic effect is associated with improved health outcomes. A prebiotic is "a selectively fermented ingredient that allows specific changes, both in the composition and/or in the activity in the gastrointestinal microflora, conferring benefits upon host well-being and health" [139]. Because HMO are only partially digested in the small intestine, they can reach the colon intact where they selectively stimulate the development of bifidogenic flora. A recent study has demonstrated the bifidogenic effect of major fucosylated and sialylated HMO when fed as a sole source of carbon to 25 major isolates of the human intestinal microbiota [140]. Most of the Bifidobacteria spp. and Bacteroides spp. were able to consume those OS and to produce short chain fatty acids, while common pathogenic bacteria were not able to grow on those OS. In vitro biological activities of HMO have been supported by in vivo studies. One of the newest publications in this topic demonstrated the ability of 2-fucosyllactose and 3-fucosyllactose to selectively increase some intestinal bacteria populations like Barnesiella, the major bacterial genus in mice [141], being this effect correlated with reduced level of colitis.

Prebiotic activities of COS, recovered from caprine whey, have been evaluated by in vitro studies [142]. The purified COS fraction favored the development of Bifidobacterium spp. and produced short chain fatty acids such as lactic and propionic acids but presented no inhibition of Staphylococcus aureus and Escherichia coli grown in human faeces.

3.2.2. Antipathogenic Activity. A second feature of OS is the ability to reduce pathogen biding to the intestinal mucosa. The intestinal mucosa is heavily glycosylated and covered with complex glycans including glycoproteins, glycolipids, and mucins, among others [143, 144]. Bacteria and viruses are able to recognize certain types of fucosylated and sialylated OS and adhere to them [130], therefore acting as anti-infective agents. Milk OS are also fucosylated and sialylated so bacteria and viruses, in presence of OS, will attach less to intestinal cells. The ability of pathogens to bind to specific OS seems to be intrinsically correlated with their structure. Neutral OS containing HexNAc block adhesion of pathogens that cause diarrhea (Vibrio cholerae) and pneumonia (Streptococcus pneumoniae) $[15,145]$, while neutral fucosylated OS have been shown to inhibit adhesion of other pathogens (i.e., Campylobacter jejuni and diarrheagenic E. coli) that cause gastrointestinal disorders [146]. Acidic OS containing sialic acid are able to block adhesion of Helicobacter pylori, which causes peptic ulcers and other gastric diseases [147], Staphylococcus aureus, and Clostridium botulinum [148].

Recent in vitro studies have demonstrated that $\mathrm{BMO}$ also possess antibacterial properties as observed for HMO. BMO from colostrum permeate proved to be effective in protecting HEp-2 cells from enteropathogenic E. coli, Cronobacter sakazakii, and Salmonella enterica serovar typhimurium [149]. It has also been demonstrated that BMO can inhibit the pili-mediated adhesion of Neisseria meningitidis in vitro [150]. Several studies have demonstrated the inhibition of the attachment of enteric pathogens such as E. coli and Campylobacter jejuni and noroviruses with HMO [151]. This effect has also been demonstrated by in vivo studies in which isolated HMO were fed to suckling mice before and after infection with enteropathogenic E. coli. Mice that received HMO significantly reduced colonization of this species compared with untreated controls [152].

3.2.3. Anti-Inflammatory Activity. OS have been also considered as anti-inflammatory agents due to their prebiotic activities and their ability to act as receptors of microorganisms. In vivo studies have demonstrated that COS possess anti-inflammatory properties towards the development of experimental colitis in rats. Pretreatment of the rats with isolated COS reduced the typical signs of induced colitis, including less anorexia, better body weight gain, and less macroscopic intestinal lesions, among others [153]. Similar results were observed by Lara-Villoslada et al. [154], where COS were shown to play an important role in intestinal protection and repair after a damage caused by DSS in rats.

\section{Future Prospects}

Milk has long been recognized as a source of macro- and micronutrients. Recent identification of many important biologically active substances on milk and its derivatives has attracted much attention from the scientific community. Not only are many of these bioactive compounds associated with growth, but they also confer many health benefits that might support disease prevention. Milk proteins and peptides are usually well tolerated and demonstrate oral bioavailability. In this view, they have the potential to act as health promoting ingredients and to participate in auxiliary therapies to boost 
TABLE 3: Biological activities of human, bovine, and goat oligosaccharides.

\begin{tabular}{|c|c|c|c|c|c|}
\hline Microorganisms/animals & Molecule used & Dose & Duration/details & Outcome measured & Reference \\
\hline $\begin{array}{l}\text { Bifidobacterium spp., } \\
\text { Bacteroides spp., } \\
\text { Clostridium spp., } \\
\text { Lactobacillus spp., } \\
\text { Enterococcus spp., } \\
\text { Streptococcus spp., } \\
\text { Staphylococcus spp., } \\
\text { Enterobacter spp., and } \\
\text { Escherichia coli }\end{array}$ & $\begin{array}{c}\operatorname{HMO}\left(2^{\prime}-\mathrm{FL}, 3^{\prime}-\mathrm{FL},\right. \\
\mathrm{LDFT}, 3^{\prime}-\mathrm{SL} \text { and } \\
\left.6^{\prime}-\mathrm{SL}\right)\end{array}$ & $0.5-2 \mathrm{~g} / \mathrm{L}$ & $48 \mathrm{hrs}$ OS incubation & $\begin{array}{l}\text { SCFA quantification, } \\
\text { bacterial growth, and } \\
\text { OS consumption }\end{array}$ & {$[140]$} \\
\hline Mice & $\begin{array}{c}\mathrm{HMO}\left(2^{\prime}-\mathrm{FL} \text { and }\right. \\
\left.3^{\prime}-\mathrm{FL}\right)\end{array}$ & $\begin{array}{l}500 \mathrm{mM} \text {, starting with } \\
5 \mathrm{~mL} \text {, increasing by } \\
2.5 \mathrm{~mL} \text { every } 3 \mathrm{~d} \\
\text { reaching a daily } \\
\text { amount of } 25 \mathrm{~mL} \text { on } \\
\text { day } 20\end{array}$ & $\begin{array}{c}\text { From day } 1 \text { to day } 20 \\
\text { after birth }\end{array}$ & $\begin{array}{l}\text { Bacterial amount, } \\
\text { colitis signs }\end{array}$ & {$[141]$} \\
\hline Bacteria from human feces & Pooled GOS & & During incubation & Bacterial amount & [142] \\
\hline Mice & Pooled HMO & $15 \mathrm{mg} /$ day & $\begin{array}{l}\text { One day before and } \\
\text { after infection with } \\
\text { EPEC }\end{array}$ & $\begin{array}{c}\text { Intestinal } \\
\text { colonization of EPEC }\end{array}$ & {$[152]$} \\
\hline HEp-2 cells & $\begin{array}{l}\text { Pooled BMO from } \\
\text { colostrum }\end{array}$ & $\begin{array}{l}20 \mathrm{mg} / \mathrm{L} \text { of total } \\
\text { carbohydrate in } \\
\text { culture }\end{array}$ & During incubation & Adherence inhibition & [149] \\
\hline $\begin{array}{l}\text { Bovine thyroglobulin and } \\
\text { human salivary agglutinin } \\
\text { glycoproteins }\end{array}$ & $\begin{array}{l}\text { Pooled HMO and } \\
\text { BMO }\end{array}$ & $40 \mathrm{~g} / \mathrm{L}$ & During incubation & $\begin{array}{l}\text { Neisseria meningitidis } \\
\text { Pili attachment }\end{array}$ & {$[150]$} \\
\hline Rats & Pooled GOS & $500 \mathrm{mg} /(\mathrm{kg} * \mathrm{~d})$ & $\begin{array}{c}2 \text { days before and } 6 \\
\text { days after induced } \\
\text { colitis }\end{array}$ & Colonic damage & {$[153]$} \\
\hline
\end{tabular}

HMO: human milk oligosaccharides; FL: fucosyllactose; LDFT: lacto-difucosyl-tetraose; SL: sialyllactose; GOS: galacto-oligosaccharides; BMO: bovine milk oligosaccharides.

overall success in chronic diseases. However, this research area is only at its beginning and more peptides with physiological effects are to be discovered in the future. Confirming the health benefits of these bioactive compounds requires the design of clinical trials based on metabolomic genomics, proteomics, transcriptomics, and epigenetic data, in order to explore new biomarkers related to the observed health benefits.

While larger data for in vivo biological activities of milk and peptides is observed, the same is not observed for OS. To date, few studies have demonstrated the safety and efficacy of OS supplementation $[155,156]$. The reduced number of biological activities evaluated for BMO and COS reveals the challenges associated with the production of OS in adequate quantities and purity needed for clinical trials. The development of new synthetic pathways to produce highly purified OS and of large-scale processes to recover those OS from their respective industrial streams will likely improve the elucidation of their biological activities and determine their safety and efficacy in clinical trials with humans. Moreover, the development of more environmentally friendly processes that are also economically feasible not only will enable the production of a new generation of prebiotics but will address environmental issues associated with the disposal of OScontaining waste streams and poor economic viability of our food industry.

\section{Conflict of Interests}

The authors declare that there is no conflict of interests regarding the publication of this paper.

\section{Acknowledgments}

The authors acknowledge funding from the National Institute of Health, the "Bill and Melinda Gates Foundation," and the Peter J. Shields Chair in Dairy Food Science at the University of California at Davis. Chia-Chien Hsieh acknowledges the Ministry of Science and Technology for National Science Council of Taiwan (MOST 103-2320-B-003-003-MY3). Samuel Fernández-Tomé and Blanca Hernández-Ledesma acknowledge the Ministry of Economy and Competitiveness (MINECO) for their FPI fellowship and "Ramón y Cajal" postdoctoral contract, respectively. 


\section{References}

[1] B. Lamarche, "Review of the effect of dairy products on nonlipid risk factors for cardiovascular disease," Journal of the American College of Nutrition, vol. 27, no. 6, pp. 741S-746S, 2008.

[2] C. Jaffiol, "Milk and dairy products in the prevention and therapy of obesity, type 2 diabetes and metabolic syndrome," Bulletin de l'Academie Nationale de Medecine, vol. 192, no. 4, pp. 749-758, 2008.

[3] K. Uenishi, "Prevention of osteoporosis by foods and dietary supplements. Prevention of osteoporosis by milk and dairy products," Clinical Calcium, vol. 16, no. 10, pp. 1606-1614, 2006.

[4] Y. Shimazaki, T. Shirota, K. Uchida et al., "Intake of dairy products and periodontal disease: the Hisayama study," Journal of Periodontology, vol. 79, no. 1, pp. 131-137, 2008.

[5] C. M. Weaver, "Should dairy be recommended as part of a healthy vegetarian diet? Point," The American Journal of Clinical Nutrition, vol. 89, no. 5, pp. 1634S-1637S, 2009.

[6] M. Pufulete, "Intake of dairy products and risk of colorectal neoplasia," Nutrition Research Reviews, vol. 21, no. 1, pp. 56-67, 2008.

[7] E. Ginter, "Vegetarian diets, chronic diseases and longevity," Bratislavské Lekárske Listy, vol. 109, no. 10, pp. 463-466, 2008.

[8] R. Nagpal, P. V. Behare, M. Kumar et al., "Milk, milk products, and disease free health: an updated overview," Critical Reviews in Food Science and Nutrition, vol. 52, no. 4, pp. 321-333, 2012.

[9] R. Nagpal, P. Behare, R. Rana et al., "Bioactive peptides derived from milk proteins and their health beneficial potentials: an update," Food and Function, vol. 2, no. 1, pp. 18-27, 2011.

[10] D. S. Newburg, "Neonatal protection by an innate immune system of human milk consisting of oligosaccharides and glycans," Journal of Animal Science, vol. 87, no. 13, pp. 26-34, 2009.

[11] G. V. Coppa, P. Pierani, L. Zampini, I. Carloni, A. Carlucci, and O. Gabrielli, "Oligosaccharides in human milk during different phases of lactation," Acta Paediatrica, vol. 88, no. 430, pp. 89-94, 1999.

[12] O. Ballard and A. L. Morrow, "Human milk composition: nutrients and bioactive factors," Pediatric Clinics of North America, vol. 60, no. 1, pp. 49-74, 2013.

[13] D. S. Newburg and S. H. Neubauer, "Carbohydrates in milks: analysis, quantities, and significance," in Handbook of Milk Composition, R. G. Jensen, Ed., chapter 4, pp. 273-349, Academic Press, San Diego, Calif, USA, 1995.

[14] M. B. Engfer, B. Stahl, B. Finke, G. Sawatzki, and H. Daniel, "Human milk oligosaccharides are resistant to enzymatic hydrolysis in the upper gastrointestinal tract," American Journal of Clinical Nutrition, vol. 71, no. 6, pp. 1589-1596, 2000.

[15] G. V. Coppa, L. Zampini, T. Galeazzi et al., "Human milk oligosaccharides inhibit the adhesion to Caco-2 cells of diarrheal pathogens: Escherichia coli, Vibrio cholerae, and Salmonella fyris," Pediatric Research, vol. 59, no. 3, pp. 377-382, 2006.

[16] S. E. Carlson and S. G. House, "Oral and intraperitoneal administration of $N$-acetylneuraminic acid: effect on rat cerebral and cerebellar $\mathrm{N}$-acetylneuraminic acid," Journal of Nutrition, vol. 116, no. 5, pp. 881-886, 1986.

[17] N. Klein, A. Schwertmann, M. Peters, C. Kunz, and S. Strobe, "Immunomodulatory effects of breast milk oligosaccharides", in Short and Long Term Effects of Breast Feeding on Child Health, B. Koletzko, K. F. Michaelsen, and O. Hernell, Eds., pp. 251-259, Springer, New York, NY, USA, 2002.
[18] D. Divajeva, T. Marsh, S. Logstrup et al., "Economics of chronic diseases protocol: cost-effectiveness modelling and the future burden of non-communicable disease in Europe," BMC Public Health, vol. 14, no. 1, article 456, 2014.

[19] W. Y. Huang, S. T. Davidge, and J. Wu, "Bioactive natural constituents from food sources-potential use in hypertension prevention and treatment," Critical Reviews in Food Science and Nutrition, vol. 53, no. 6, pp. 615-630, 2013.

[20] S. G. Chrysant and G. S. Chrysant, "An update on the cardiovascular pleiotropic effects of milk and milk products," The Journal of Clinical Hypertension, vol. 15, no. 7, pp. 503-510, 2013.

[21] M. F. Engberink, M. A. H. Hendriksen, E. G. Schouten et al., "Inverse association between dairy intake and hypertension: the rotterdam study," The American Journal of Clinical Nutrition, vol. 89, no. 6, pp. 1877-1883, 2009.

[22] L. A. J. van Mierlo, L. R. Arends, M. T. Streppel et al., "Blood pressure response to calcium supplementation: a meta-analysis of randomized controlled trials," Journal of Human Hypertension, vol. 20, no. 8, pp. 571-580, 2006.

[23] R. J. Fitzgerald, B. A. Murray, and D. J. Walsh, "Hypotensive peptides from milk proteins," Journal of Nutrition, vol. 134, no. 4, 2004.

[24] D. Martínez-Maqueda, B. Miralles, I. Recio, and B. HernándezLedesma, "Antihypertensive peptides from food proteins: a review," Food \& Function, vol. 3, no. 4, pp. 350-361, 2012.

[25] B. Hernández-Ledesma, M. J. García-Nebot, S. FernándezTomé, L. Amigo, and I. Recio, "Dairy protein hydrolysates: peptides for health benefits," International Dairy Journal, vol. 38, no. 2, pp. 82-100, 2014.

[26] M. D. M. Contreras, R. Carrón, M. J. Montero, M. Ramos, and I. Recio, "Novel casein-derived peptides with antihypertensive activity," International Dairy Journal, vol. 19, no. 10, pp. 566-573, 2009.

[27] I. Recio, M. M. Contreras, B. Gómez-Sala, C. Vázquez, H. Fernández-Escribano, and R. del Campo, "Effect of a casein hydrolysate containing novel peptides in hypertensive subjects," Annals of Nutrition and Metabolism, vol. 58, no. 3, pp. 16-17, 2011.

[28] P. Ruiz-Giménez, M. C. Burguete, M. Castelló-Ruiz et al., "Bovine lactoferrin pepsin hydrolysate exerts inhibitory effect on angiotensin I-converting enzyme-dependent vasoconstriction," International Dairy Journal, vol. 17, no. 10, pp. 1212-1215, 2007.

[29] P. Ruiz-Giménez, J. B. Salom, J. F. Marcos et al., "Antihypertensive effect of a bovine lactoferrin pepsin hydrolysate: identification of novel active peptides," Food Chemistry, vol. 131, no. 1, pp. 266-273, 2012.

[30] R. Fernández-Musoles, P. Manzanares, M. C. Burguete, E. Alborch, and J. B. Salom, "In vivo angiotensin I-converting enzyme inhibition by long-term intake of antihypertensive lactoferrin hydrolysate in spontaneously hypertensive rats," Food Research International, vol. 54, no. 1, pp. 627-632, 2013.

[31] R. Sugai, U. Murakami, and Y. Yamori, "Angiotensin converting enzyme inhibitors," Japanese Patent, 62270533, 1995.

[32] J. A. Cadée, C.-Y. Chang, C.-W. Chen, C.-N. Huang, S.-L. Chen, and C.-K. Wang, "Bovine casein hydrolysate (c12 Peptide) reduces blood pressure in prehypertensive subjects," American Journal of Hypertension, vol. 20, no. 1, pp. 1-5, 2007.

[33] A. Abubakar, T. Saito, H. Kitazawa, Y. Kawai, and T. Itoh, "Structural analysis of new antihypertensive peptides derived from cheese whey protein by proteinase K digestion," Journal of Dairy Science, vol. 81, no. 12, pp. 3131-3138, 1998. 
[34] G.-W. Chen, J.-S. Tsai, and B. Sun Pan, "Purification of angiotensin I-converting enzyme inhibitory peptides and antihypertensive effect of milk produced by protease-facilitated lactic fermentation," International Dairy Journal, vol. 17, no. 6, pp. 641647, 2007.

[35] B. Hernández-Ledesma, M. Miguel, L. Amigo, M. A. Aleixandre, and I. Recio, "Effect of simulated gastrointestinal digestion on the antihypertensive properties of synthetic $\beta$-lactoglobulin peptide sequences," Journal of Dairy Research, vol. 74, no. 3, pp. 336-339, 2007.

[36] J.-S. Tsai, T.-J. Chen, B. S. Pan, S.-D. Gong, and M.-Y. Chung, "Antihypertensive effect of bioactive peptides produced by protease-facilitated lactic acid fermentation of milk," Food Chemistry, vol. 106, no. 2, pp. 552-558, 2008.

[37] Y. Nakamura, N. Yamamoto, K. Sakai, A. Okubo, S. Yamazaki, and T. Takano, "Purification and characterization of angiotensin I-converting enzyme inhibitors from sour milk," Journal of Dairy Science, vol. 78, no. 4, pp. 777-783, 1995.

[38] Y. Nakamura, N. Yamamoto, K. Sakai, and T. Takano, "Antihypertensive effect of sour milk and peptides isolated from it that are inhibitors to angiotensin I-converting enzyme," Journal of Dairy Science, vol. 78, no. 6, pp. 1253-1257, 1995.

[39] A. H. Pripp, "Effect of peptides derived from food proteins on blood pressure: a meta-analysis of randomized controlled trials," Food and Nutrition Research, vol. 52, pp. 1-9, 2008.

[40] J.-Y. Xu, L.-Q. Qin, P.-Y. Wang, W. Li, and C. Chang, "Effect of milk tripeptides on blood pressure: a meta-analysis of randomized controlled trials," Nutrition, vol. 24, no. 10, pp. 933940, 2008.

[41] L.-Q. Qin, J.-Y. Xu, J.-Y. Dong, Y. Zhao, P. van Bladeren, and W. Zhang, "Lactotripeptides intake and blood pressure management: a meta-analysis of randomised controlled clinical trials," Nutrition, Metabolism and Cardiovascular Diseases, vol. 23, no. 5, pp. 395-402, 2013.

[42] M. F. Engberink, E. G. Schouten, F. J. Kok, L. A. J. van Mierlo, I. A. Brouwer, and J. M. Geleijnse, "Lactotripeptides show no effect on human blood pressure: results from a double-blind randomized controlled trial," Hypertension, vol. 51, no. 2, pp. 399-405, 2008.

[43] L. Usinger, L. T. Jensen, B. Flambard, A. Linneberg, and H. Ibsen, "The antihypertensive effect of fermented milk in individuals with prehypertension or borderline hypertension," Journal of Human Hypertension, vol. 24, no. 10, pp. 678-683, 2010.

[44] A. F. G. Cicero, B. Gerocarni, L. Laghi, and C. Borghi, "Blood pressure lowering effect of lactotripeptides assumed as functional foods: a meta-analysis of current available clinical trials," Journal of Human Hypertension, vol. 25, no. 7, pp. 425-436, 2011.

[45] A. F. G. Cicero, F. Aubin, V. Azais-Braesco, and C. Borghi, "Do the lactotripeptides isoleucine-proline-proline and valine-proline-proline reduce systolic blood pressure in european subjects? A meta-analysis of randomized controlled trials," American Journal of Hypertension, vol. 26, no. 3, pp. 442-449, 2013.

[46] EFSA Panel on Dietetic Products Nutrition and Allergies (NDA), "Scientific opinion on the substantion of health claims related to isoleucineproline-proline (IPP) and valine-prolineproline (VPP) and maintenance of normal blood pressure (ID 615, 661, 1831, 1832, 2891), and maintenance of the elastic properties of the arteries (ID 1832) pursuant to Article 13(1) of regulation (EC) No 1924/2006 on request from the European Commission," EFSA Journal, vol. 7, pp. 1259-1277, 2009.

[47] M. Miguel, I. Recio, M. Ramos, M. A. Delgado, and M. A. Aleixandre, "Antihypertensive effect of peptides obtained from
Enterococcus faecalis-fermented milk in rats," Journal of Dairy Science, vol. 89, no. 9, pp. 3352-3359, 2006.

[48] J. C. Rodríguez-Figueroa, A. F. González-Córdova, M. J. TorresLlanez, H. S. Garcia, and B. Vallejo-Cordoba, "Novel angiotensin I-converting enzyme inhibitory peptides produced in fermented milk by specific wild Lactococcus lactis strains," Journal of Dairy Science, vol. 95, no. 10, pp. 5536-5543, 2012.

[49] J. C. Rodríguez-Figueroa, A. F. González-Córdova, H. Astiazaran-García, and B. Vallejo-Cordoba, "Hypotensive and heart rate-lowering effects in rats receiving milk fermented by specific Lactococcus lactis strains," British Journal of Nutrition, vol. 109, no. 5, pp. 827-833, 2013.

[50] K. Erdmann, B. W. Y. Cheung, and H. Schröder, "The possible roles of food-derived bioactive peptides in reducing the risk of cardiovascular disease," The Journal of Nutritional Biochemistry, vol. 19, no. 10, pp. 643-654, 2008.

[51] A. Pihlanto, "Antioxidative peptides derived from milk proteins," International Dairy Journal, vol. 16, no. 11, pp. 1306-1314, 2006.

[52] O. Power, P. Jakeman, and R. J. Fitzgerald, "Antioxidative peptides: enzymatic production, in vitro and in vivo antioxidant activity and potential applications of milk-derived antioxidative peptides," Amino Acids, vol. 44, no. 3, pp. 797-820, 2013.

[53] M. Zommara, H. Toubo, M. Sakono, and K. Imaizumi, "Prevention of peroxidative stress in rats fed on a low vitamin e-containing diet by supplementing with a fermented bovine milk whey preparation: effect of lactic acid and $\beta$-lactoglobulin on the antiperoxidative action," Bioscience, Biotechnology and Biochemistry, vol. 62, no. 4, pp. 710-717, 1998.

[54] T. Kullisaar, E. Songisepp, M. Mikelsaar, K. Zilmer, T. Vihalemm, and M. Zilmer, "Antioxidative probiotic fermented goats' milk decreases oxidative stress-mediated atherogenicity in human subjects," British Journal of Nutrition, vol. 90, no. 2, pp. 449-456, 2003.

[55] G. Tompa, A. Laine, A. Pihlanto, H. Korhonen, I. Rogelj, and P. Marnilab, "Chemiluminescence of non-differentiated THP-1 promonocytes: developing an assay for screening anti-inflammatory milk proteins and peptides," The Journal of Biological and Chemical Luminiscence, vol. 26, no. 4, pp. 251-258, 2010.

[56] X.-Y. Mao, X. Cheng, X. Wang, and S.-J. Wu, "Free-radical-scavenging and anti-inflammatory effect of yak milk casein before and after enzymatic hydrolysis," Food Chemistry, vol. 126, no. 2, pp. 484-490, 2011.

[57] K. D. Ballard, R. S. Bruno, R. L. Seip et al., "Acute ingestion of a novel whey-derived peptide improves vascular endothelial responses in healthy individuals: a randomized, placebo controlled trial," Nutrition Journal, vol. 8, article 34, 2009.

[58] S. Nagaoka, Y. Kanamaru, and Y. Kuzuya, "Effects of whey protein and casein on the plasma and liver lipids in rats," Agricultural and Biological Chemistry, vol. 55, no. 3, pp. 813-818, 1991.

[59] S. Nagaoka, Y. Kanamaru, Y. Kuzuya, T. Kojima, and T. Kuwata, "Comparative studies on the serum cholesterol lowering action of the whey protein and soybean protein in rats," Bioscience, Biotechnology and Biochemistry, vol. 56, no. 9, pp. 1484-1485, 1992.

[60] S. Nagaoka, Y. Futamura, K. Miwa et al., "Identification of novel hypocholesterolemic peptides derived from bovine milk $\beta$ lactoglobulin," Biochemical and Biophysical Research Communications, vol. 281, no. 1, pp. 11-17, 2001. 
[61] R. Yamauchi, K. Ohinata, and M. Yoshikawa, “ $\beta$-Lactotensin and neurotensin rapidly reduce serum cholesterol via NT2 receptor," Peptides, vol. 24, no. 12, pp. 1955-1961, 2003.

[62] M. Shimizu, "Interaction between food substances and the intestinal epithelium," Bioscience, Biotechnology and Biochemistry, vol. 74, no. 2, pp. 232-241, 2010.

[63] M. Shimizu, "Functional food in Japan: current status and future of gut-modulating food," Journal of Food and Drug Analysis, vol. 20, no. 1, pp. 213-216, 2012.

[64] J. Claustre, F. Toumi, A. Trompette et al., "Effects of peptides derived from dietary proteins on mucus secretion in rat jejunum," American Journal of Physiology-Gastrointestinal and Liver Physiology, vol. 283, no. 3, pp. G521-G528, 2002.

[65] A. Trompette, J. Claustre, F. Caillon, G. Jourdan, J. A. Chayvialle, and P. Plaisancié, "Milk bioactive peptides and $\beta$-casomorphins induce mucus release in rat jejunum," Journal of Nutrition, vol. 133, no. 11, pp. 3499-3503, 2003.

[66] S. Zoghbi, A. Trompette, J. Claustre et al., “ $\beta$-Casomorphin-7 regulates the secretion and expression of gastrointestinal mucins through a $\mu$-opioid pathway," American Journal of Physiology-Gastrointestinal and Liver Physiology, vol. 290, no. 6, pp. G1105-G1113, 2006.

[67] P. Plaisancié, J. Claustre, M. Estienne et al., "A novel bioactive peptide from yoghurts modulates expression of the gel-forming MUC2 mucin as well as population of goblet cells and Paneth cells along the small intestine," Journal of Nutritional Biochemistry, vol. 24, no. 1, pp. 213-221, 2013.

[68] D. Martínez-Maqueda, B. Miralles, M. Ramos, and I. Recio, "Effect of $\beta$-lactoglobulin hydrolysate and $\beta$-lactorphin on intestinal mucin secretion and gene expression in human goblet cells," Food Research International, vol. 54, no. 1, pp. 1287-1291, 2013.

[69] K. S. Han, A. Deglaire, R. Sengupta, and P. J. Moughan, "Hydrolyzed casein influences intestinal mucin gene expression in the rat," Journal of Agricultural and Food Chemistry, vol. 56, no. 14, pp. 5572-5576, 2008.

[70] R. C. Sprong, A. J. Schonewille, and R. van der Meer, "Dietary cheese whey protein protects rats against mild dextran sulfate sodium-induced colitis: role of mucin and microbiota," Journal of Dairy Science, vol. 93, no. 4, pp. 1364-1371, 2010.

[71] M. Faure, C. Mettraux, D. Moennoz et al., "Specific amino acids increase mucin synthesis and microbiota in dextran sulfate sodium-treated rats," Journal of Nutrition, vol. 136, no. 6, pp. 1558-1564, 2006.

[72] G. A. Castro, J. E. Carvalho, S. V. Tinti, A. Possenti, and V. C. Sgarbieri, "Anti-ulcerogenic effect of a whey protein isolate and collagen hydrolysates against ethanol ulcerative lesions on oral administration to rats," Journal of Medicinal Food, vol. 13, no. 1, pp. 83-90, 2010.

[73] L. F. H. Mezzaroba, J. E. Carvalho, A. N. Ponezi et al., "Antiulcerative properties of bovine $\alpha$-lactalbumin," International Dairy Journal, vol. 16, no. 9, pp. 1005-1012, 2006.

[74] S. S. Comstock, E. A. Reznikov, N. Contractor, and S. M. Donovan, "Dietary bovine lactoferrin alters mucosal and systemic immune cell responses in neonatal piglets," Journal of Nutrition, vol. 144, no. 4, pp. 525-532, 2014.

[75] Z. Tang, Y. Yin, Y. Zhang et al., "Effects of dietary supplementation with an expressed fusion peptide bovine lactoferricinlactoferrampin on performance, immune function and intestinal mucosal morphology in piglets weaned at age $21 \mathrm{~d}$," British Journal of Nutrition, vol. 101, no. 7, pp. 998-1005, 2009.
[76] G. A. Biziulevičius, V. Žukaite, T. Normantiene, G. Biziulevičiene, and I. G. Arestov, "Non-specific immunity-enhancing effects of tryptic casein hydrolysate versus Fermosorb for treatment/prophylaxis of newborn calf colibacillosis," FEMS Immunology and Medical Microbiology, vol. 39, no. 2, pp. 155$161,2003$.

[77] H. Otani, K. Nakano, and T. Kawahara, "Stimulatory effect of a dietary casein phosphopeptide preparation on the mucosal IgA response of mice to orally ingested lipopolysaccharide from Salmonella typhimurium," Bioscience, Biotechnology and Biochemistry, vol. 67, no. 4, pp. 729-735, 2003.

[78] G. Vinderola, C. Matar, and G. Perdigón, "Milk fermentation products of $L$. helveticus $\mathrm{R} 389$ activate calcineurin as a signal to promote gut mucosal immunity," BMC Immunology, vol. 8, no. 19, pp. 19-28, 2007.

[79] H. Kitamura and H. Otani, "Fecal IgA levels in healthy persons who ingested cakes with or without bovine casein phosphopeptides," Milchwissenschaft, vol. 57, no. 11-12, pp. 611-614, 2002.

[80] D. E. W. Chatterton, D. N. Nguyen, S. B. Bering, and P. T. Sangild, "Anti-inflammatory mechanisms of bioactive milk proteins in the intestine of newborns," The International Journal of Biochemistry \& Cell Biology, vol. 45, no. 8, pp. 1730-1747, 2013.

[81] F. S. De Medina, A. Daddaoua, P. Requena et al., "New insights into the immunological effects of food bioactive peptides in animal models of intestinal inflammation," Proceedings of the Nutrition Society, vol. 69, no. 3, pp. 454-462, 2010.

[82] G. T. Sousa, F. S. Lira, J. C. Rosa et al., "Dietary whey protein lessens several risk factors for metabolic diseases: a review," Lipids in Health and Disease, vol. 11, article 67, 2012.

[83] A. S. Gad, Y. A. Khadrawy, A. A. El-Nekeety, S. R. Mohamed, N. S. Hassan, and M. A. Abdel-Wahhab, "Antioxidant activity and hepatoprotective effects of whey protein and Spirulina in rats," Nutrition, vol. 27, no. 5, pp. 582-589, 2011.

[84] E. M. Hamad, S. H. Taha, A.-G. I. Abou Dawood, M. Z. Sitohy, and M. Abdel-Hamid, "Protective effect of whey proteins against nonalcoholic fatty liver in rats," Lipids in Health and Disease, vol. 10, article 57, 2011.

[85] T. Chitapanarux, P. Tienboon, S. Pojchamarnwiputh, and D. Leelarungrayub, "Open-labeled pilot study of cysteine-rich whey protein isolate supplementation for nonalcoholic steatohepatitis patients," Journal of Gastroenterology and Hepatology, vol. 24, no. 6, pp. 1045-1050, 2009.

[86] J. E. de Aguilar-Nascimento, B. R. Prado Silveira, and D. B. Dock-Nascimento, "Early enteral nutrition with whey protein or casein in elderly patients with acute ischemic stroke: a double-blind randomized trial," Nutrition, vol. 27, no. 4, pp. 440-444, 2011.

[87] R. López-Posadas, P. Requena, R. González et al., "Bovine glycomacropeptide has intestinal antiinflammatory effects in rats with dextran sulfate-induced colitis," Journal of Nutrition, vol. 140, no. 11, pp. 2014-2019, 2010.

[88] P. Requena, A. Daddaoua, E. Martínez-Plata et al., "Bovine glycomacropeptide ameliorates experimental rat ileitis by mechanisms involving downregulation of interleukin 17," British Journal of Pharmacology, vol. 154, no. 4, pp. 825-832, 2008.

[89] M. B. E. Turbay, A. de Moreno de LeBlanc, G. Perdigón, G. S. de Giori, and E. M. Hebert, " $\beta$-Casein hydrolysate generated by the cell envelope-associated proteinase of Lactobacillus delbrueckii ssp. lactis CRL 581 protects against trinitrobenzene sulfonic acid-induced colitis in mice," Journal of Dairy Science, vol. 95, no. 3, pp. 1108-1118, 2012. 
[90] R. E. Pratley and A. Salsali, "Inhibition of DPP-4: a new therapeutic approach for the treatment of type 2 diabetes," Current Medical Research and Opinion, vol. 23, no. 4, pp. 919931, 2007.

[91] T. Reihner, "Type 2 diabetes in children and adolescents," World Journal of Diabetes, vol. 4, no. 6, pp. 270-281, 2013.

[92] K. M. Hirahatake, J. L. Slavin, K. C. Maki, and S. H. Adams, "Associations between dairy foods, diabetes, and metabolic health: potential mechanisms and future directions," Metabolism: Clinical and Experimental, vol. 63, no. 5, pp. 618-627, 2014.

[93] D. J. Drucker and M. A. Nauck, “The incretin system: glucagonlike peptide-1 receptor agonists and dipeptidyl peptidase- 4 inhibitors in type 2 diabetes," The Lancet, vol. 368, no. 9548, pp. 1696-1705, 2006.

[94] P. V. Bharatam, D. S. Patel, L. Adane, A. Mittal, and S. Sundriyal, "Modeling and informatics and designing anti-diabetic agents," Current Pharmaceutical Design, vol. 13, no. 34, pp. 3518-3530, 2007.

[95] M. A. Nauck, N. Kleine, C. Ørskov, J. J. Holst, B. Willms, and W. Creutzfeldt, "Normalization of fasting hyperglycaemia by exogenous glucagon-like peptide 1 (7-36 amide) in Type 2 (noninsulin-dependent) diabetic patients," Diabetologia, vol. 36, no. 8, pp. 741-744, 1993.

[96] G. P. Fadini and A. Avogaro, "Cardiovascular effects of DPP-4 inhibition: beyond GLP-1," Vascular Pharmacology, vol. 55, no. 1-3, pp. 10-16, 2011.

[97] P. T. Gunnarsson, M. S. Winzell, C. F. Deacon et al., "Glucoseinduced incretin hormone release and inactivation are differently modulated by oral fat and protein in mice," Endocrinology, vol. 147, no. 7, pp. 3173-3180, 2006.

[98] B. L. Petersen, L. S. Ward, E. D. Bastian, A. L. Jenkins, J. Campbell, and V. Vuksan, "A whey protein supplement decreases post-prandial glycemia," Nutrition Journal, vol. 8, article 47, 2009.

[99] G. T. D. Sousa, F. S. Lira, J. C. Rosa et al., "Dietary whey protein lessens several risk factors for metabolic diseases: a review," Lipids in Health and Disease, vol. 11, article 67, 2012.

[100] T. Akhavan, B. L. Luhovyy, P. H. Brown, C. E. Cho, and G. $\mathrm{H}$. Anderson, "Effect of premeal consumption of whey protein and its hydrolysate on food intake and postmeal glycemia and insulin responses in young adults," American Journal of Clinical Nutrition, vol. 91, no. 4, pp. 966-975, 2010.

[101] C. Gaudel, A. B. Nongonierma, S. Maher et al., "A whey protein hydrolysate promotes insulinotropic activity in a clonal pancreatic $\beta$-cell line and enhances glycemic function in ob/ob mice," Journal of Nutrition, vol. 143, no. 7, pp. 1109-1114, 2013.

[102] A. B. Nongonierma and R. J. Fitzgerald, "Dipeptidyl peptidase IV inhibitory and antioxidative properties of milk proteinderived dipeptides and hydrolysates," Peptides, vol. 39, no. 1, pp. 157-163, 2013.

[103] S. T. Silveira, D. Martínez-Maqueda, I. Recio, and B. Hernández-Ledesma, "Dipeptidyl peptidase-IV inhibitory peptides generated by tryptic hydrolysis of a whey protein concentrate rich in $\beta$-lactoglobulin," Food Chemistry, vol. 141, no. 2, pp. 1072-1077, 2013.

[104] G. Tulipano, V. Sibilia, A. M. Caroli, and D. Cocchi, "Whey proteins as source of dipeptidyl dipeptidase IV (dipeptidyl peptidase-4) inhibitors," Peptides, vol. 32, no. 4, pp. 835-838, 2011.

[105] M. Uchida, Y. Ohshiba, and O. Mogami, "Novel dipeptidyl peptidase-4-inhibiting peptide derived from $\beta$-lactoglobulin,"
Journal of Pharmacological Sciences, vol. 117, no. 1, pp. 63-66, 2011.

[106] H. Uenishi, T. Kabuki, Y. Seto, A. Serizawa, and H. Nakajima, "Isolation and identification of casein-derived dipeptidylpeptidase 4 (DPP-4)-inhibitory peptide LPQNIPPL from gouda-type cheese and its effect on plasma glucose in rats," International Dairy Journal, vol. 22, no. 1, pp. 24-30, 2012.

[107] I. M. E. Lacroix and E. C. Y. Li-Chan, "Evaluation of the potential of dietary proteins as precursors of dipeptidyl peptidase (DPP)-IV inhibitors by an in silico approach," Journal of Functional Foods, vol. 4, no. 2, pp. 403-422, 2012.

[108] A. B. Nongonierma, C. Mooney, D. C. Shields, and R. J. Fitzgerald, "In silico approaches to predict the potential of milk protein-derived peptides as dipeptidyl peptidase IV (DPP-IV) inhibitors," Peptides, vol. 57, pp. 43-51, 2014.

[109] F. Bray and B. Møller, "Predicting the future burden of cancer," Nature Reviews Cancer, vol. 6, no. 1, pp. 63-74, 2006.

[110] M. M. Manson, "Cancer prevention-the potential for diet to modulate molecular signalling," Trends in Molecular Medicine, vol. 9, no. 1, pp. 11-18, 2003.

[111] T. M. de Kok, S. G. van Breda, and M. M. Manson, "Mechanisms of combined action of different chemopreventive dietary compounds," European Journal of Nutrition, vol. 47, no. 2, supplement, pp. 51-59, 2008.

[112] E. G. De Mejia and V. P. Dia, “The role of nutraceutical proteins and peptides in apoptosis, angiogenesis, and metastasis of cancer cells," Cancer and Metastasis Reviews, vol. 29, no. 3, pp. 511-528, 2010.

[113] R. K. Kanwar and J. R. Kanwar, "Immunomodulatory lactoferrin in the regulation of apoptosis modulatory proteins in cancer," Protein \& Peptide Letters, vol. 20, no. 4, pp. 450-458, 2013.

[114] S. J. Furlong, J. S. Mader, and D. W. Hoskin, "Bovine lactoferricin induces caspase-independent apoptosis in human Blymphoma cells and extends the survival of immune-deficient mice bearing B-lymphoma xenografts," Experimental and Molecular Pathology, vol. 88, no. 3, pp. 371-375, 2010.

[115] G. Pepe, G. C. Tenore, R. Mastrocinque, P. Stusio, and P. Campiglia, "Potential anticarcinogenic peptides from bovine milk," Journal of Amino Acids, vol. 2013, Article ID 939804, 7 pages, 2013.

[116] J. S. Mader, D. Smyth, J. Marshall, and D. W. Hoskin, "Bovine lactoferricin inhibits basic fibroblast growth factor- and vascular endothelial growth factor165-induced angiogenesis by competing for heparin-like binding sites on endothelial cells," The American Journal of Pathology, vol. 169, no. 5, pp. 1753-1766, 2006.

[117] Y. C. Yoo, S. Watanabe, R. Watanabe, K. Hata, K. I. Shimazaki, and I. Azuma, "Bovine lactoferrin and lactoferricin, a peptide derived from bovine lactoferrin, inhibit tumor metastasis in mice," Japanese Journal of Cancer Research, vol. 88, no. 2, pp. 184-190, 1997.

[118] L. Tone Eliassen, G. Berge, B. Sveinbjørnsson, J. S. Svendsen, L. H. Vorland, and Ø. Rekdal, "Evidence for a direct antitumor mechanism of action of bovine lactoferricin," Anticancer Research, vol. 22, no. 5, pp. 2703-2710, 2002.

[119] L. T. Eliassen, G. Berge, A. Leknessund et al., "The antimicrobial peptide, Lactoferricin B, is cytotoxic to neuroblastoma cells in vitro and inhibits xenograft growth in vivo," International Journal of Cancer, vol. 119, no. 3, pp. 493-500, 2006. 
[120] C. R. Brinkmann, S. Thiel, and D. E. Otzen, "Protein-fatty acid complexes: biochemistry, biophysics and function," FEBS Journal, vol. 280, no. 8, pp. 1733-1749, 2013.

[121] A.-K. Mossberg, Y. Hou, M. Svensson, B. Holmqvist, and C. Svanborg, "HAMLET treatment delays bladder cancer development," The Journal of Urology, vol. 183, no. 4, pp. 1590-1597, 2010.

[122] S. Perego, S. Cosentino, A. Fiorilli, G. Tettamanti, and A. Ferraretto, "Casein phosphopeptides modulate proliferation and apoptosis in HT-29 cell line through their interaction with voltage-operated L-type calcium channels," Journal of Nutritional Biochemistry, vol. 23, no. 7, pp. 808-816, 2012.

[123] S. Perego, A. Zabeo, E. Marasco et al., "Casein phosphopeptides modulate calcium uptake and apoptosis in Caco2 cells through their interaction with the TRPV6 calcium channel," Journal of Functional Foods, vol. 5, no. 2, pp. 847-857, 2013.

[124] A. Hatzoglou, E. Bakogeorgou, C. Hatzoglou, P.-M. Martin, and E. Castanas, "Antiproliferative and receptor binding properties of $\alpha$ - and $\beta$-casomorphins in the T47D human breast cancer cell line," European Journal of Pharmacology, vol. 310, no. 2-3, pp. 217-223, 1996.

[125] R. Maneckjee, R. Biswas, and B. K. Vonderhaar, "Binding of opioids to human MCF-7 breast cancer cells and their effects on growth," Cancer Research, vol. 50, no. 8, pp. 2234-2238, 1990.

[126] V. Packard, Human Milk and Infant Formula, Elsevier/ Academic Press, New York, NY, USA, 2012.

[127] A. M. Zivkovic and D. Barile, "Bovine milk as a source of functional oligosaccharides for improving human health," Advances in Nutrition, vol. 2, no. 3, pp. 284-289, 2011.

[128] D. Barile and R. A. Rastall, "Human milk and related oligosaccharides as prebiotics," Current Opinion in Biotechnology, vol. 24, no. 2, pp. 214-219, 2013.

[129] M. Lange, D. C. Dallas, A. le Parc, J. M. L. N. de Moura Bell, and D. Barile, "Human nutrition: determining functional properties ans sources of recently identified food components: oligosaccharides, glycolipids, glycoproteins and peptides," in Encyclopedia of Agriculture and Food Systems, N. van Alfen, Ed., 461, p. 441, Elsevier, New York, NY, USA, 2014.

[130] G. Boehm and G. Moro, "Structural and functional aspects of prebiotics used in infant nutrition," Journal of Nutrition, vol. 138, no. 9, pp. 1818S-1828S, 2008.

[131] G. R. Gibson and M. B. Roberfroid, "Dietary modulation of the human colonic microbiota: introducing the concept of prebiotics," Journal of Nutrition, vol. 125, no. 6, pp. 1401-1412, 1995.

[132] T. Urashima, E. Taufik, K. Fukuda, and S. Asakuma, "Recent advances in studies on milk oligosaccharides of cows and other domestic farm animals," Bioscience, Biotechnology and Biochemistry, vol. 77, no. 3, pp. 455-466, 2013.

[133] D. Barile, M. Marotta, C. Chu et al., "Neutral and acidic oligosaccharides in Holstein-Friesian colostrum during the first 3 days of lactation measured by high performance liquid chromatography on a microfluidic chip and time-of-flight mass spectrometry," Journal of Dairy Science, vol. 93, no. 9, pp. 39403949, 2010.

[134] K. Mariño, J. A. Lane, J. L. Abrahams et al., "Method for milk oligosaccharide profiling by 2 -aminobenzamide labeling and hydrophilic interaction chromatography," Glycobiology, vol. 21, no. 10, pp. 1317-1330, 2011.

[135] R. W. Veh, J.-C. Michalski, A. P. Corfield, M. Sander-Wewer, D. Gies, and R. Schauer, "New chromatographic system for the rapid analysis and preparation of colostrum sialyloligosaccharides," Journal of Chromatography A, vol. 212, no. 3, pp. 313-322, 1981.

[136] M. Meyrand, D. C. Dallas, H. Caillat, F. Bouvier, P. Martin, and D. Barile, "Comparison of milk oligosaccharides between goats with and without the genetic ability to synthesize $\alpha$ sl-casein," Small Ruminant Research, vol. 113, no. 2-3, pp. 411-420, 2013.

[137] A. Martinez-Ferez, S. Rudloff, A. Guadix et al., "Goats' milk as a natural source of lactose-derived oligosaccharides: isolation by membrane technology," International Dairy Journal, vol. 16, no. 2, pp. 173-181, 2006.

[138] D. Barile, N. Tao, C. B. Lebrilla, J.-D. Coisson, M. Arlorio, and J. B. German, "Permeate from cheese whey ultrafiltration is a source of milk oligosaccharides," International Dairy Journal, vol. 19, no. 9, pp. 524-530, 2009.

[139] M. Roberfroid, "Prebiotics: the concept revisited," The Journal of Nutrition, vol. 137, supplement 2, no. 3, pp. 830S-837S, 2007.

[140] Z.-T. Yu, C. Chen, and D. S. Newburg, "Utilization of major fucosylated and sialylated human milk oligosaccharides by isolated human gut microbes," Glycobiology, vol. 23, no. 11, pp. 1281-1292, 2013.

[141] G. A. Weiss, C. Chassard, and T. Hennet, "Selective proliferation of intestinal Barnesiella under fucosyllactose supplementation in mice," British Journal of Nutrition, vol. 111, no. 9, pp. 16021610, 2014.

[142] D. L. Oliveira, A. Costabile, R. A. Wilbey, A. S. Grandison, L. C. Duarte, and L. B. Roseiro, "In vitro evaluation of the fermentation properties and potential prebiotic activity of caprine cheese whey oligosaccharides in batch culture systems," BioFactors, vol. 38, no. 6, pp. 440-449, 2012.

[143] C. Nagler-Anderson, "Man the barrier! Strategic defences in the intestinal mucosa," Nature Reviews Immunology, vol. 1, no. 1, pp. 59-67, 2001.

[144] D. S. Newburg and W. A. Walker, "Protection of the neonate by the innate immune system of developing gut and of human milk," Pediatric Research, vol. 61, no. 1, pp. 2-8, 2007.

[145] H. H. Tong, M. A. McIver, L. M. Fisher, and T. F. DeMaria, "Effect of lacto-N-neotetraose, asialoganglioside-GM1 and neuraminidase on adherence of otitis media-associated serotypes of Streptococcus pneumoniae to chinchilla tracheal epithelium," Microbial Pathogenesis, vol. 26, no. 2, pp. 111-119, 1999.

[146] A. L. Morrow, G. M. Ruiz-Palacios, M. Altaye et al., "Human milk oligosaccharides are associated with protection against diarrhea in breast-fed infants," Journal of Pediatrics, vol. 145, no. 3, pp. 297-303, 2004.

[147] P. M. Simon, P. L. Goode, A. Mobasseri, and D. Zopf, "Inhibition of Helicobacter pylori binding to gastrointestinal epithelial cells by sialic acid-containing oligosaccharides," Infection and Immunity, vol. 65, no. 2, pp. 750-757, 1997.

[148] A. Imberty, Y. M. Chabre, and R. Roy, "Glycomimetics and glycodendrimers as high affinity microbial anti-adhesins," Chemistry, vol. 14, no. 25, pp. 7490-7499, 2008.

[149] M. X. Maldonado-Gómez, H. Lee, D. Barile, M. Lu, and R. W. Hutkins, "Adherence inhibition of enteric pathogens to epithelial cells by bovine colostrum fractions," International Dairy Journal, vol. 40, pp. 24-32, 2015.

[150] J. Hakkarainen, M. Toivanen, A. Leinonen et al., "Human and bovine milk oligossaccharides inhibit Neisseria meningitidis pili attachment in vitro," Journal of Nutrition, vol. 135, no. 10, pp. 2445-2448, 2005. 
[151] D. S. Newburg, G. M. Ruiz-Palacios, and A. L. Morrow, "Human milk glycans protect infants against enteric pathogens," Annual Review of Nutrition, vol. 25, no. 1, pp. 37-58, 2005.

[152] C. F. Manthey, C. A. Autran, L. Eckmann, and L. Bode, "Human milk oligosaccharides protect against enteropathogenic Escherichia coli attachment in vitro and EPEC colonization in suckling mice," Journal of Pediatric Gastroenterology and Nutrition, vol. 58, no. 2, pp. 165-168, 2014.

[153] A. Daddaoua, V. Puerta, P. Requena et al., "Goat milk oligosaccharides are anti-inflammatory in rats with hapten-induced colitis," Journal of Nutrition, vol. 136, no. 3, pp. 672-676, 2006.

[154] F. Lara-Villoslada, E. Debras, A. Nieto et al., "Oligosaccharides isolated from goat milk reduce intestinal inflammation in a rat model of dextran sodium sulfate-induced colitis," Clinical Nutrition, vol. 25, no. 3, pp. 477-488, 2006.

[155] C. Ashley, W. H. Johnston, C. L. Harris, S. I. Stolz, J. L. Wampler, and C. L. Berseth, "Growth and tolerance of infants fed formula supplemented with polydextrose (PDX) and/or galactooligosaccharides (GOS): double-blind, randomized, controlled trial," Nutrition Journal, vol. 11, no. 1, article 38, 2012.

[156] S. Fanaro, B. Marten, R. Bagna et al., "Galacto-oligosaccharides are bifidogenic and safe at weaning: a double-blind randomized multicenter study," Journal of Pediatric Gastroenterology and Nutrition, vol. 48, no. 1, pp. 82-88, 2009.

[157] M. E. Davis, A. Rao, S. Gauthier, Y. Pouliot, L. Gourley, and A. Allain, "Preparing an aqueous solution of whey protein isolate and a proteolytic enzyme, holding solution under conditions effective to partially hydrolyze whey protein isolate to provide a hydrolysate having increased ACE-suppressing activity in mammals," US Patent, 6998259, 2006.

[158] I. Recio, I. López-Expósito, A. Quirós et al., "Bioactive peptides identified in enzymatic hydrolyzates of milk caseins and method of obtaining same," WO Patent, 131586, 2006.

[159] O. Tossavainen, T. Suomalainen, J. Sahlstein, and A. M. Makinen, "Process for producing a product containing antihypertensive tripeptides," US Patent, 6972282 B1, 2005.

[160] E. Damiens, I. Yazidi, J. Mazurier, I. Duthile, G. Spik, and Y. Boilly-Marer, "Lactoferrin inhibits G1 cyclin-dependent kinases during growth arrest of human breast carcinoma cells," Journal of Cellular Biochemistry, vol. 74, no. 3, pp. 486-498, 1999.

[161] X. Sun, R. Jiang, A. Przepiorski, S. Reddy, K. P. Palmano, and G. W. Krissansen, “Iron-saturated' bovine lactoferrin improves the chemotherapeutic effects of tamoxifen in the treatment of basal-like breast cancer in mice," BMC Cancer, vol. 12, article 591, 2012.

[162] B. Fang, M. Zhang, M. Tian, L. Jiang, H. Y. Guo, and F. Z. Ren, "Bovine lactoferrin binds oleic acid to form an anti-tumor complex similar to HAMLET," Biochimica et Biophysica ActaMolecular and Cell Biology of Lipids, vol. 1841, no. 4, pp. 535-543, 2014.

[163] J. S. Mader, J. Salsman, D. M. Conrad, and D. W. Hoskin, "Bovine lactoferricin selectively induces apoptosis in human leukemia and carcinoma cell lines," Molecular Cancer Therapeutics, vol. 4, no. 4, pp. 612-624, 2005.

[164] H. M. Habib, W. H. Ibrahim, R. Schneider-Stock, and H. M. Hassan, "Camel milk lactoferrin reduces the proliferation of colorectal cancer cells and exerts antioxidant and DNA damage inhibitory activities," Food Chemistry, vol. 141, no. 1, pp. 148-152, 2013.

[165] J. R. Kanwar, G. Mahidhara, and R. K. Kanwar, "Novel alginateenclosed chitosan-calcium phosphate-loaded iron-saturated bovine lactoferrin nanocarriers for oral delivery in colon cancer therapy," Nanomedicine, vol. 7, no. 10, pp. 1521-1550, 2012.

[166] C. Freiburghaus, B. Janicke, H. Lindmark-Månsson, S. M. Oredsson, and M. A. Paulsson, "Lactoferricin treatment decreases the rate of cell proliferation of a human colon cancer cell line," Journal of Dairy Science, vol. 92, no. 6, pp. 2477-2484, 2009.

[167] C. Freiburghaus, H. Lindmark-Månsson, M. Paulsson, and S. Oredsson, "Reduction of ultraviolet light-induced DNA damage in human colon cancer cells treated with a lactoferrinderived peptide," Journal of Dairy Science, vol. 95, no. 10, pp. 5552-5560, 2012.

[168] N. Zemann, P. Klein, E. Wetzel, F. Huettinger, and M. Huettinger, "Lactoferrin induces growth arrest and nuclear accumulation of Smad-2 in HeLa cells," Biochimie, vol. 92, no. 7, pp. 880$884,2010$.

[169] A. Varadhachary, J. S. Wolf, K. Petrak et al., "Oral lactoferrin inhibits growth of established tumors and potentiates conventional chemotherapy,' International Journal of Cancer, vol. 111, no. 3, pp. 398-403, 2004.

[170] Y.-C. Yoo, R. Watanabe, Y. Koike et al., "Apoptosis in human leukemic cells induced by lactoferricin, a bovine milk proteinderived peptide: involvement of reactive oxygen species," Biochemical and Biophysical Research Communications, vol. 237, no. 3, pp. 624-628, 1997.

[171] J. S. Mader, A. Richardson, J. Salsman et al., "Bovine lactoferricin causes apoptosis in Jurkat T-leukemia cells by sequential permeabilization of the cell membrane and targeting of mitochondria," Experimental Cell Research, vol. 313, no. 12, pp. 2634-2650, 2007.

[172] T.-N. Zhang and N. Liu, "Effect of bovine lactoferricin on DNA methyltransferase 1 levels in Jurkat T-leukemia cells," Journal of Dairy Science, vol. 93, no. 9, pp. 3925-3930, 2010.

[173] G. Berge, L. T. Eliassen, K. A. Camilio, K. Bartnes, B. Sveinbjørnsson, and $\varnothing$. Rekdal, "Therapeutic vaccination against a murine lymphoma by intratumoral injection of a cationic anticancer peptide," Cancer Immunology, Immunotherapy, vol. 59, no. 8, pp. 1285-1294, 2010.

[174] Y. T. Tung, H. L. Chen, C. C. Yen et al., "Bovine lactoferrin inhibits lung cancer growth through suppression of both inflammation and expression of vascular endothelial growth factor," Journal of Dairy Science, vol. 96, no. 4, pp. 2095-2106, 2013.

[175] M. Deng, W. Zhang, H. Tang et al., "Lactotransferrin acts as a tumor suppressor in nasopharyngeal carcinoma by repressing AKT through multiple mechanisms," Oncogene, vol. 32, no. 36, pp. 4273-4283, 2013.

[176] T. Sakai, Y. Banno, Y. Kato, Y. Nozawa, and M. Kawaguchi, "Pepsin-digested bovine lactoferrin induces apoptotic cell death with JNK/SAPK activation in oral cancer cells," Journal of Pharmacological Sciences, vol. 98, no. 1, pp. 41-48, 2005. 

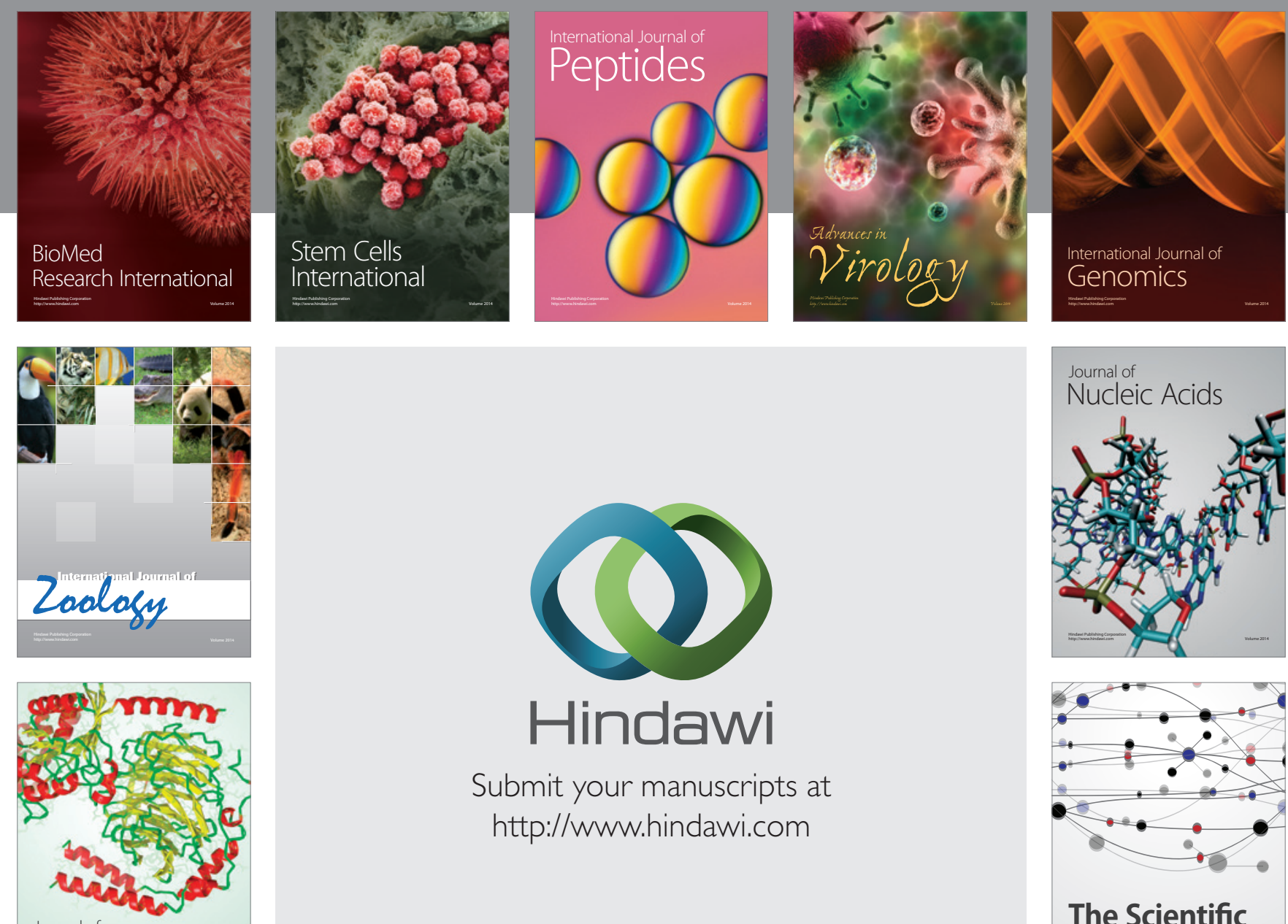

Submit your manuscripts at

http://www.hindawi.com

Journal of
Signal Transduction
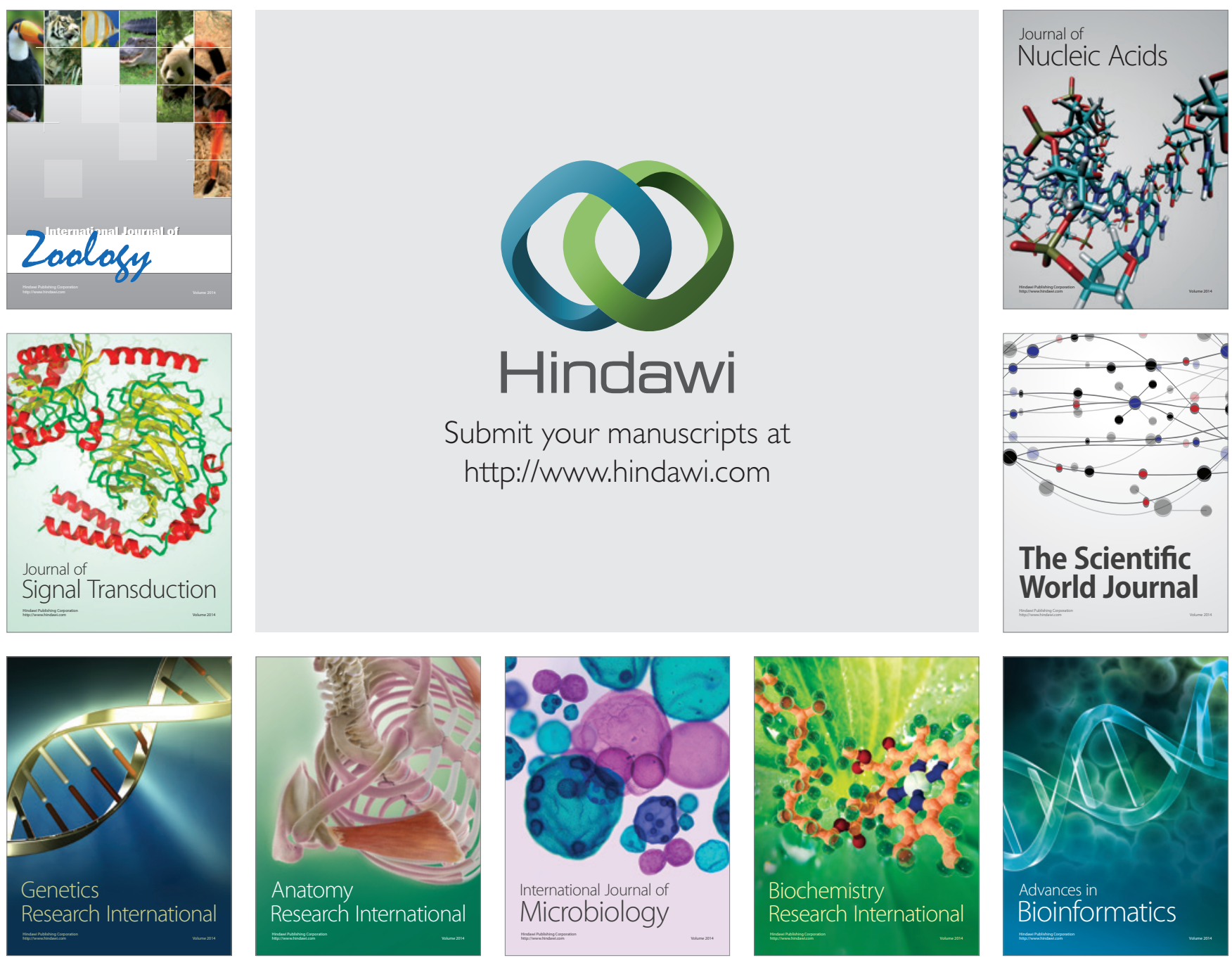

The Scientific World Journal
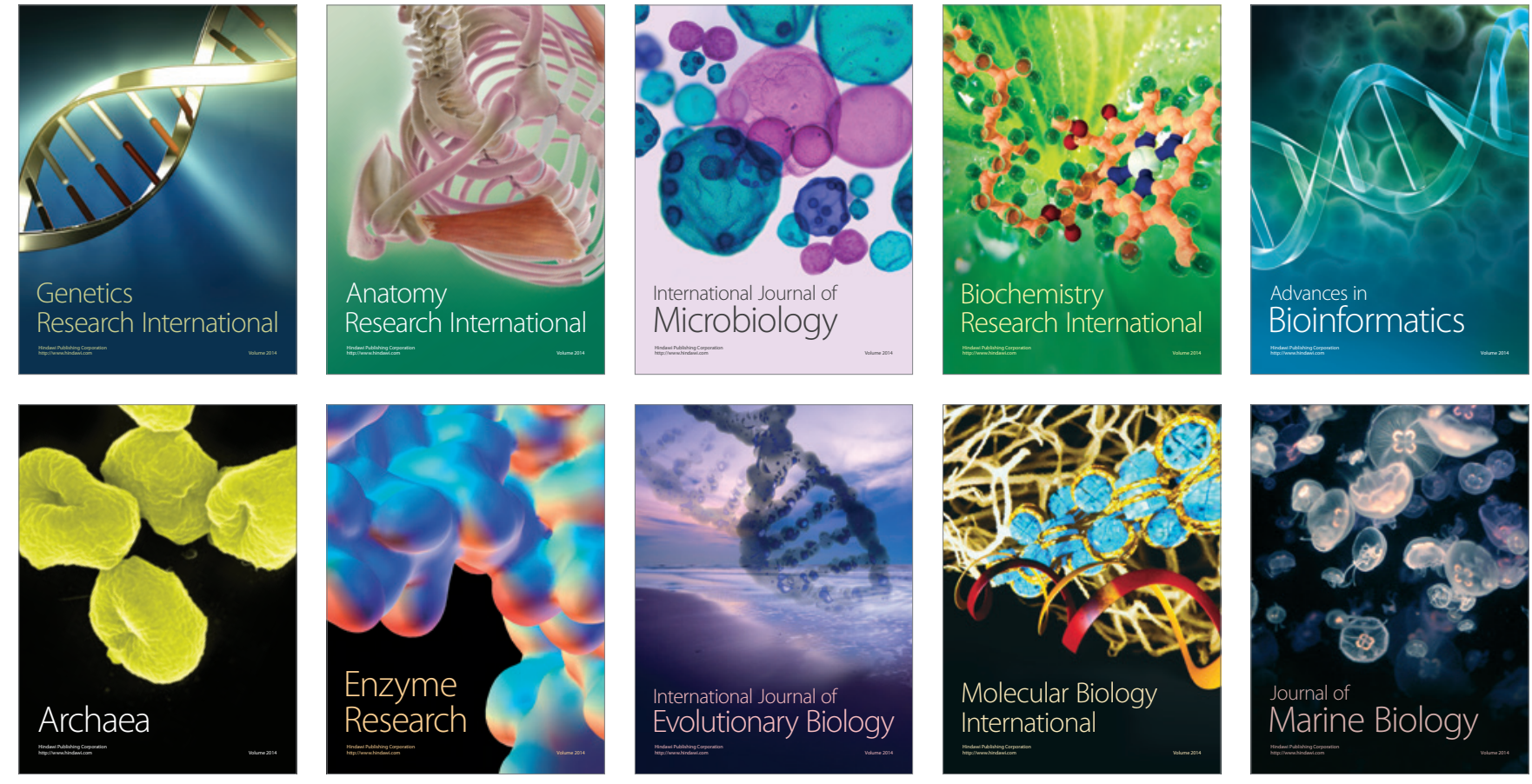